\title{
Multiple dolomitization episodes in deep-water limestones of the Triassic Lagonegro basin (southern Italy): from early reflux to tectonically-driven fluid-flow
}

Running title: Multiple dolomitization episodes in deep-water limestones

Tatyana Gabellone $^{1^{*}}$, Alessandro Iannace ${ }^{1}$, Marta Gasparrini ${ }^{2}$

${ }^{1}$ Dipartimento di Scienze della Terra, dell'Ambiente e delle Risorse, Università di Napoli Federico

II; Largo San Marcellino, 10, 80138, Napoli, Italy (tatyana.gabellone@bristol.ac.uk, aleianna@unina.it).

${ }^{2}$ IFP Energies nouvelles, 1 \& 4 Av. de Bois-Préau, 92852, Rueil-Malmaison, France (marta.gasparrini@ifpen.fr).

Corresponding author: Tatyana Gabellone

*new address: School of Earth Sciences, University of Bristol

Wills Memorial Building

Queen's Road

Bristol, BS8 1RJ, UK

Phone: +44 (0) 1179545415

E-mail: tatyana.gabellone@bristol.ac.uk 


\begin{abstract}
Massive dolomitization does not commonly occur in deep-water carbonates. However, this regional study on outcrops and subsurface samples of Triassic Lagonegro basinal carbonates from the southern Apennines fold and thrust belt (Italy) shows that the evolution of the Lagonegro basin was punctuated by two events of massive dolomitization. These processes resulted in two distinct dolomite types, displaying different petrographic and geochemical features. A medium crystalline and fabric preservative dolomite in the northern area (Molise, Campagna and San Fele-Mount Pierno) contrasts with a medium to coarse crystalline and fabric destructive dolomite in the southern area (from Pignola to the high Val d'Agri).

Geochemical data (enrichment in $\delta^{18} \mathrm{O}$ with respect to typical Upper Triassic seawater values, high $\mathrm{Sr}$ and low $\mathrm{Mn}$ and Fe content, $\mathrm{Sr}$ isotopes consistent with Upper Triassic seawater) indicate that the dolomite in the northern area is the result of an early replacement caused by a marine and possibly oxidizing fluid during shallow burial. Dolomitizing fluids likely were expelled through a reflux from the Norian Apenninic carbonate platform towards the proximal Lagonegro basin. This reflux was promoted by the Norian peculiar palaeoceanographic and climatic conditions in the Tethyan region, and affected only the proximal basinal facies.

Dolomites in the southern area display a depletion in $\delta^{18} \mathrm{O}$ compared to Upper Triassic seawater values and show lower $\mathrm{Sr}$, higher $\mathrm{Mn}$ and Fe contents, and higher $\mathrm{Sr}$ isotopes ratios compared to the early dolomites of the northern area. Fluid inclusions microthermometry reveals homogenization temperatures between 70 and $120^{\circ} \mathrm{C}$ and salinities of 1.9 to $6.4 \mathrm{wt} \% \mathrm{NaCl}$ eq. for saddle dolomites. These geochemical signatures indicate that the southern area was affected by late diagenetic burial dolomitization, interpreted to be the result of a large scale tectonically-driven fluid-flow during the second compressional phase characterizing the southern Apennines fold and thrust belt emplacement.
\end{abstract}


The dolomite distribution across the Lagonegro basin (northern and southern) is possibly controlled by the paleogeographic distribution of the facies (proximal vs. distal) as well as by their proximity to thrust faults. The Lagonegro case-study demonstrates that basinal successions may undergo multiple dolomitization episodes in a similar manner to carbonate platform successions, from early shallow to deep burial diagenesis. One of the relevant implication is that within areas of restricted oceanographic circulation, during periods of aridity, reflux dolomitization may extend beyond the platform margin, into deep-water carbonates, this having the potential to alter their reservoir quality.

Keywords: southern Apennines, Norian, reflux, zebra dolomite, Val d'Agri

\section{INTRODUCTION}

Shallow-water carbonates can be affected by dolomitization at different stages of sedimentary basin evolution, from early, surface-related processes, to deep burial diagenesis and even postexhumation alteration. In contrast, deep-water slope and basinal carbonates are dolomitized less commonly. The paucity of massive dolomitization in deep-water basins could be due to the fact that basinal successions commonly are composed of low-Mg calcite, which is less prone to dolomitize than high-Mg calcite and aragonite, that in contrast, can be abundant in platform successions. Minor volumes of dolomite are found in deep-sea pelagic sediments as thin layers and nodules (Kelts and McKenzie 1982, and references therein), as well as in slope sediments (Coniglio and James 1988), and are related to bacterial sulfate reduction and methanogenesis. The uncommon occurrence of massive dolomite in slope and basinal successions generally is associated to late diagenesis unrelated to surface processes, such as hydrothermal phenomena (Cervato 1990), up-dip fluid-flow from basin dewatering (Mresah 1998), or geothermal convection of marine derived pore fluids (Kohout 1965; Dewever 2008). Only few examples exist of slope to basin dolomitization related to early, near-surface processes, such as downward evaporitic brine reflux (Clark 1980; Fu et al. 
2006). Understanding the local occurrence of massive dolomites, not only in platform sediments but even in slope and basinal successions, is of economic interest, as the dolomitization mechanism has the potential to improve the reservoir quality of the precursor rocks (Sun 1995; Saller and Handerson 1998).

In the Lagonegro basin succession of the southern Apennines mountain belt (Italy), Triassic deepwater cherty limestones constitute the Calcari con selce Formation. It has been known since the second half of the last century (Scandone 1967) that these hemipelagic limestones commonly are replaced by massive dolomite, especially in the shallow (over $1500 \mathrm{~m}$ of depth) and proximal (up to $\sim 40 \mathrm{~km}$ from the platform margin) areas of the basin (Miconnet 1988). Based on these observations, Passeri et al. (2005) proposed downward reflux of evaporitic brines as the most probable dolomitization mechanism. Conversely, Iannace et al. (2012) reported the occurrence of saddle dolomite and zebra textures (Beales and Hardie 1980; Wallace et al. 1994; Nielsen et al. 1998; Merino et al. 2006) in three outcrops of the Lagonegro basin, and proposed a burial origin related to Neogene tectonics of the southern Apennines fold and thrust belt. Recently, fluid inclusion and geochemical analyses on syntectonic calcite and quartz veins and on saddle dolomite specimens from both outcrops and wells have improved the characterization of the fluid source for the Lagonegro zebra dolomite, and their temporal relationship with the activation of a major thrust zone (Gabellone et al. 2013). The dolomites from the Lagonegro basin, are a rare example of massive dolomites in a deep-water carbonate succession, thus providing an intriguing case-study of basinwide dolomitization, whose origin appear, according to existing literature, still controversial (Scandone 1967; Miconnet 1988; Passeri 2005; Iannace 2012; Gabellone et al. 2013).

Here, a systematic regional study on the dolomite distribution within the Lagonegro basin of a large number of outcrops and subsurface samples was completed by petrographic observations and geochemical analyses. The aims of this research were: (i) to evaluate the extent of the dolomitization phenomenon at a regional scale, (ii) to characterize the different chemical-physical 
diagenetic environments, and (iii) to understand which factors (climate, tectonics, platform architecture) may play an important role in promoting massive dolomitization in analog basinal successions.

\section{GEOLOGICAL SETTING}

The southern Apennines are a NE-directed fold and thrust belt, formed by progressive collision between Africa and Europe plates during Neogene (Mazzoli and Helman 1994, and references therein), with the Apulian promontory representing the orogenic foreland (Fig. 1). The classic restoration of the pre-orogenic (Triassic to Paleogene) palaeogeography of the southern Apennines shows that the African (Apulian) passive margin was characterized by the Meso-Cenozoic pelagic Lagonegro basin, located between two coeval carbonate platforms: the Apenninic and Apulian (Fig. 2). The subsequent closure of the Lagonegro basin was related to collisional tectonics towards the north, where more proximal facies are located (Scandone 1967; Miconnet 1988).

The hemipelagic succession of the Lagonegro basin (Fig. 3) starts with the Monte Facito Formation (Fm.) (FAC), given by Lower to Middle Triassic shelfal, fine-grained siliciclastics containing carbonate buildups with dasycladacean algae and sponges (Scandone 1967; Ciarapica et al. 1990). The overlying Calcari con selce Formation (SLC), Upper Triassic in age, consists mainly of micritic limestone containing thin-shelled bivalves and radiolarians, with beds and nodules of chert. According to previous literature (Scandone 1967; Passeri et al. 2005) the Calcari con selce Formation locally consists of calcarenites (corresponding to packstone textures) and calcirudites (corresponding to rudstone textures), both interpreted as resedimented detrital carbonates, as well as marls. This formation actually is dolomitic in many outcrops of the Lagonegro succession (Scandone 1967). The Scisti Silicei (STS), Flysch Galestrino (FYG) and Flysch Rosso (FYR) formations represent the truly deep-water to fore-deep stage of the basin evolution. 
The study area can be subdivided into a southern and northern area (Fig. 4). The Lagonegro basin outcrops are located mainly in the southern area, in Lucania region, specifically around the Lagonegro village, and in high Val d'Agri (Fig. 4 and 5). More limited outcrops occur in the northern area, which includes the tectonic window of Campagna, the San Fele and Mount Pierno outcrops and the Mount Marrone succession in the Molise region (Fig. 4). Seismic profiles across the same area (Mostardini and Merlini 1986), and further to the south in the Ionian Sea (Finetti 2005), document the presence of the Lagonegro units in the subsurface, tectonically underlying the carbonate rocks of the Apenninic platform unit.

The deformation history of the Lagonegro basin was first outlined by Scandone (1972) who recognized, at a regional scale, the presence of two superimposed nappes. These were named Lagonegro Unit II (upper nappe) and Lagonegro Unit I (lower nappe). Mazzoli et al. (2001, and references therein) proposed the following structural evolution. From Triassic to Oligocene, the southern Apennines were in a passive margin phase. In Miocene time, a first phase of thrusting and buckling caused the closure of the Lagonegro basin. During the Pliocene, a second phase of thrusting led to the regional superposition of the Lagonegro units. Subsequently, the emplacement of the allochthonous wedge above the westernmost portion of the Apulian platform formed the structural traps hosting at present the major oil fields of southern Italy (Shiner et al. 2004). Afterwards, gravitational readjustments dominated within the allochthonous wedge, triggering denudation and tectonic exhumation (assisted by erosion, Mazzoli et al. 2008). Finally, active shortening migrated to the underlying Apulian crust, producing basement-involved inversion at depth.

The detachment between the allochthonous wedge and the buried Apulian shallow-water carbonates is marked by a melange zone up to several hundred meters thick (Fig. 1). The latter consists mainly of intensely deformed and overpressured deep-water Miocene to Lower Pliocene mudstone and siltstone (Mazzoli et al. 2001; Butler et al. 2004; Shiner et al. 2004). 
Thermal and thermochronological data from outcrops enabled the reconstruction of the Lagonegro basin history (Aldega et al. 2003, 2005; Corrado et al. 2005; Mazzoli et al. 2008). The Val d'Agri area (in the north) recorded a maximum burial of $3.8 \mathrm{~km}$ and a peak temperature ranging from 130 to $160{ }^{\circ} \mathrm{C}$, reached during the first thrusting phase (Miocene). The second phase of thrusting was accompanied by exhumation, as indicated by apatite fission track data, providing cooling ages through the $\sim 110{ }^{\circ} \mathrm{C}$ isotherm clustering around 5.5 Ma (Mazzoli et al. 2008). The Lagonegro village area (in the south) experienced maximum burial over $5 \mathrm{~km}$ and peak temperatures of $180{ }^{\circ} \mathrm{C}$, whereas exhumation was younger, with apatite fission track cooling ages through the $\sim 110^{\circ} \mathrm{C}$ isotherm falling in the last 2.5 Ma (Corrado et al. 2002; Mazzoli et al. 2008).

\section{MATERIALS AND METHODS}

A field survey, including most areas where the Calcari con selce Formation crops out, was performed in order to estimate the areal extension of the dolomitization phenomenon in the Lagonegro succession (Fig. 4 and 5). A total of 125 rock specimens of dolomite and host limestone were sampled from 17 different outcrops. The main outcrops of dolomitized cherty limestones are in the southern part of the Lucania region, from Pignola to the high Val d'Agri (Fig. 4; see Fig. 5 for outcrops name and location). Dolomites occur also further to the north, in the tectonic window of Campagna, in the San Fele and Mount Pierno outcrops (Fig. 4), and in Mount Marrone successions in the Molise region (Fig. 4). This latter outcrop is interpreted as belonging to a subbasin (Molise basin) of the same, large deep-water domain (Mostardini and Merlini 1986; Patacca and Scandone 2003). No dolomite occurrence is reported in the Lagonegro basin succession cropping out further to the south, close to the Lagonegro village (Fig. 4).

Thirty-six stratigraphic well logs penetrating the Lagonegro succession, mostly located in the Val d'Agri oil fields, were viewed to investigate the distribution of dolomitized bodies in the Lagonegro 
succession in the subsurface. Fifty dolomite specimens from cuttings were collected from Acerno 1, Monte Gargaruso 1 and Monte Foi 1 wells (Fig. 4), and used for petrographic and geochemical analyses.

One hundred eleven thin sections (30 to $35 \mu \mathrm{m}$ thick) from outcrop samples and 48 thin sections from subsurface samples (cuttings) were prepared for conventional and cathodoluminescence (CL) microscopy. Twenty-two thin sections were stained with Alizarin-red S using the procedure of Dickson (1966). Petrographic observations were made with a Leica DM-EP microscope under plane transmitted light. A CITL CCL $8200 \mathrm{mk} 3$ was used for cold CL analyses. The classification of dolomite textures proposed by Sibley and Gregg (1987) was used to describe the studied dolomites. Powders for geochemical analysis were drilled from rock slabs with a dental drill. Oxygen and carbon stable isotope analyses were performed on 84 dolomite samples. About $0.5 \mathrm{mg}$ of powders were heated for 18 hours at $105^{\circ} \mathrm{C}$. The isotopic ratios were measured using a Finnigan Delta $\mathrm{S}$ Mass Spectrometer. The precision ( $1 \delta$ ) was $\pm 0.09 \%$ for the carbon and $\pm 0.13 \%$ o for the oxygen. All values are reported in per mil (\%) relative to the V-PBD international standard. The dolomite acid correction factor from Rosenbaum and Sheppard (1986) was applied.

Sr isotope measurements were performed on 8 dolomite samples using $1 \mathrm{mg}$ of powder dissolved in a $2.5 \mathrm{M} \mathrm{HCl}$ solution. The separation between the two components was done by the standard procedure of ionic exchange. The $\mathrm{Sr}$ isotope ratio was determined using a Thermal-ionization Finnigan Mat 262 Mass Spectrometer. The ${ }^{87} \mathrm{Sr} /{ }^{86} \mathrm{Sr}$ values were then normalized to a ratio of 0.1194 . The precision is better than \pm 0.000020 .

Inductively Coupled Plasma - Atomic Emission Spectrometry (ICP-AES) measurements were performed on 52 dolomite samples to determine minor elements ( $\mathrm{Sr}, \mathrm{Fe}$ and $\mathrm{Mn}$ ) concentration. Approximately $1 \mathrm{mg}$ of powder was dissolved in $1 \mathrm{ml}$ of $\mathrm{HCl} 1 \mathrm{Mol}$, diluted in $4 \mathrm{ml}$ of $\mathrm{H}_{2} \mathrm{O}$ and analyzed with an atomic spectrometer (ICP-AES). The accuracy of measurements is $< \pm 2 \%$ of the measured concentration. 
Nine double polished thick sections $(100-120 \mu \mathrm{m})$ of saddle dolomite from the southern area (Fiumarella d'Anzi, Mount Arioso, Madonna del Sasso, Mount Tigliano, Vietri di Potenza, TitoSatriano, Monte Gargaruso 1 well; Fig. 5) were used for petrographic and microthermometric fluid inclusions analyses (Gabellone et al. 2013). A Linkam MDS 600 heating-freezing stage mounted on a Nikon LV100 Eclipse was used for the microthermometry measures. Fluid inclusion petrography and microthermometry was performed through the Linksys 32 software. Different fluid inclusion assemblages (FIA) were established based on the inclusions location within the crystals, for example, crystal core, growth zones, crystal edges, etc. Microthermometry was accomplished on two-phase fluid inclusions. Homogenization temperature (Th) always to the liquid phase and ice melting temperature (Tm) were determined for 234 and 24 fluid inclusions, respectively. The accuracy of the data is about $\pm 1{ }^{\circ} \mathrm{C}$ for heating runs and about $\pm 0.1{ }^{\circ} \mathrm{C}$ for cooling runs. For some inclusions, displaying Th significantly higher $\left(>20^{\circ} \mathrm{C}\right)$ than the average Th from the same FIA, the homogenization measurement was repeated twice: if the second homogenization temperature exceeded the first one of more than $10{ }^{\circ} \mathrm{C}$, the inclusion was interpreted as leaked and the corresponding Th value was not included in the database (Goldstein and Reynolds 1994). The volumetric proportion of the liquid phase relative to the total volume was calculated for large fluid inclusions at room temperature from screen images by measuring areas. Indeed, according to Bakker and Diamond (2006), for vapor:liquid ratio of $\sim 10 \%$ the area fraction is nearly equal to the volume fraction, $\pm 4 \%$ of the measured fraction.

\section{FIELD OBSERVATIONS}

\section{Features of precursor limestones}

The undolomitized limestones of the Calcari con selce Formation in the study areas consist of dark gray, bedded mudstone to wackestone containing cm-sized chert nodules, chert beds and thin marly interlayers. Bedding-parallel stylolites, due to compaction during burial, occur in the limestone and 
locally correspond with bedding planes (Fig. 6A). These earlier stylolites are crosscut by tectonic stylolites, oriented NNE-SSW and constituting a spaced pressure solution cleavage, developed during the first compression phase of the southern Apennines (Mazzoli et al. 2001).

In the northern area (Fig. 4) the presence of proximal facies is indicated by thicker beds (3-4 meters), irregular stratification, numerous nodular or lentiform beds, coarser sediments, and scarcity of shales. Conversely, facies outcropping to the south (Fig. 4) display features suggestive of a more distal environment, such as: thin beds $(10-50 \mathrm{~cm})$, plane and parallel stratification with presence of bed-parallel and convolute laminations, and abundant shales. Northern and southern areas display different macroscopic and petrographic features.

\section{Northern area}

Strata of the Calcari con selce Formation of the northern area, which comprises the tectonic window of Campagna, the San Fele-Mount Pierno outcrops and the succession of the Mount Marrone in the Molise region (Fig. 4), appear either completely dolomitized or, more rarely, completely calcareous. No dolomitization fronts were observed in this area.

All of these outcrops are less than a few tens of meters in extension and are located in complex tectonic settings. Nevertheless the dolomitized outcrops of the Calcari con selce Formation traditionally have been stratigraphically correlated with the undolomitized ones, as they both occur below the Jurassic radiolarites of the Scisti Silicei Formation.

Dolomites outcropping in the northern area are generally medium crystalline (sensu Lucia 1995) and fabric retentive.

The dolomitized succession of the Mount Marrone (Molise) consists of thinly bedded (10 to $20 \mathrm{~cm}$ ) medium to coarse crystalline (sensu Lucia 1995) dolomites, containing nodules and lenses of chert. These dolomites are overlain by massive beds (few meters thick) of gray dolomite. 
In the tectonic window of Campagna, dolomite bodies consist of dark gray and yellowish to beige beds from 5 to $15 \mathrm{~cm}$ thick (Fig. 6B). Chert lenses and nodules are abundant. The dolomites are characterized by the presence of bed-parallel laminations and cross-laminations (Fig. 6C), retained from the precursor limestone. Locally, clastic-rich beds are interbedded with the dolomites (Fig. 6D). Veinlets of milky white saddle dolomite are common (Fig. 6C).

In Mount Pierno and San Fele outcrops the dolomitized Calcari con selce Formation consists of light gray, medium crystalline dolomite, containing chert nodules. Both massive (several meters thick) and bedded (30-40 cm thick) dolomites are present (Fig. 6E, F). The massive dolomites are characterized by dolomite-cemented vugs. The transition to the overlying Scisti Silicei Formation is marked by the presence of partially dolomitized graded calcarenites and calcirudites beds (Scandone 1967; Passeri et al. 2005), displaying packstones and rudstones textures, respectively.

\section{Southern area}

In the southern area, from Pignola to the high Val d'Agri (Fig. 4 and 5), dolomite is more scattered, and many outcrops of undolomitized limestone occur. Further to the south, in the areas close to Mount Volturino and to the Lagonegro village (Fig. 4), the Calcari con selce Formation is never dolomitized.

Dolomites of the southern area constitute irregular bodies, and undolomitized limestone tongues commonly occur within the dolomitized sections. Dolomitization fronts are common, and are usually sharp and crosscut the bedding planes (Fig. 7A). The bedding-parallel stylolites and the tectonic stylolites in the limestones occur also in the dolomitized bodies, showing the same orientations.

The southern area dolomites are mostly medium to coarse crystalline (sensu Lucia 1995) and fabric destructive. Nevertheless, some sedimentary features of the precursor limestone, such as thin 
laminations, and ghosts of radiolarians and thin-shelled bivalves, were locally recognized in the dolomites. Chert nodules and beds are also preserved in the dolomitized bodies.

All the surveyed outcrops of the southern area are characterized by the presence of zebra dolomite structures (Beales and Hardie 1980; Wallace et al. 1994; Nielsen et al. 1998; Merino et al. 2006), which consist of alternating bands of light gray replacive dolomite and white sparry void-filling dolomite (Fig. 7B-D). These zebra structures generally are confined to single beds, or group of beds, alternating with layers composed exclusively of replacive gray dolomite. They display the same features as the zebra dolomite described by Iannace et al. (2012) in the outcrop of Pignola. Locally, chert beds seem to have acted as a seal and to have exerted a control in focusing the dolomitizing fluids through the more permeable underlying carbonates (Fig. 7B). The zebra structures more commonly are oriented parallel to bedding, but locally they are obliquely oriented (Fig. 7C). Frequently, the zebra structures are crosscut by white sparry dolomite veins, which are sub-vertical with respect to the bedding and are oriented NNW-SSE (Fig. 7D). Dolomite-filled veins with the same orientations are also present in the unreplaced limestone, close to the boundaries with the fully dolomitized bodies.

Brecciated dolomite occurs locally and is made of $\mathrm{cm}$ - to dm-sized clasts of gray replacive dolomite and angular chert, both cemented by white sparry dolomite (Fig. 7E, F). The clasts of replacive dolomite display sharp boundaries and are generally broadly rectangular in shape, although smoothened to curved surfaces occur, with some local evidence of dissolution.

\section{DISTRIBUTION OF DOLOMITES IN THE SUBSURFACE}

The massive dolomites of the Triassic Calcari con selce Formation are present in four stratigraphic logs from the Val d'Agri exploration wells (Acerno 1, Monte Gargaruso 1, Monte Foi 1, San Fele 1; 
Fig. 8). Two of these wells are located in the northern area (Acerno 1 and San Fele 1; Fig. 4), whereas the other two (Monte Gargaruso 1 and Monte Foi 1) are in the southern area (Fig. 4).

The Acerno 1 well (Fig. 8) is located at the north-western margin of the Campagna tectonic window (Fig. 4). The well perforated the two Lagonegro tectonic units. From top down to $1235 \mathrm{~m}$ the Unit II contains the Calcari con selce Formation, which is dolomitized. From $1235 \mathrm{~m}$ to the bottom (4625 m), the succession is made of the Lagonegro Unit I, which is composed of stacked, minor thrust sheets. The Calcari con selce Formation in this unit is dolomitized from 3409 to $3975 \mathrm{~m}$ in the lowermost thrust sheet. The Monte Gargaruso 1 well (Fig. 8) perforated both the Lagonegro Unit I and II, in which dolomitized intervals are present at depths between 2090-2640 m and 38904200 m. The Monte Foi 1 well (Fig. 8) penetrated a thick antiformal, imbricated stack structure belonging to the Lagonegro Unit II. The Calcari con selce Formation, constituted mainly of dolomites, is encountered four times in the borehole between $319-802 \mathrm{~m}, 860-1298 \mathrm{~m}, 2298-2840$ $\mathrm{m}$ and 3035-3610 $\mathrm{m}$.

In a few other wells from the southern area (Tempa la Manara, Monte Enoc 1 and Costa Molina; pink dots in Fig. 4) only minor dolomite and dolomitic limestones are present. In all the other wells (green dots in Fig. 4), located in the southernmost area close to Mount Volturino, no dolomite occurred.

Dolomites with chert were described as well in the Frosolone 2 well (Pieri 1966), located in the Molise region (Fig. 4). Bertinelli et al. (2002) identified a resemblance between the dolomites of the Frosolone 2 well and the dolomites outcropping at Mount Marrone (Molise region). These dolomites represent the northernmost subsurface occurrence of the Lagonegro basin succession. However, this well has not been studied in detail, since cuttings were not available. 


\section{PETROGRAPHY}

\section{Precursor limestones}

Typical microfacies of the limestones of the Calcari con selce Formation are mainly mudstone and wackestone with thin-shelled bivalves and calcified radiolarians (Fig. 9A). These mudstone to wackestone units commonly are recrystallized and show a uniform dull orange to dull red CL pattern (Fig. 9B). They are crosscut by several generations of calcite veins (up to $3 \mathrm{~mm}$ in thickness), displaying a dull orange to non-luminescent CL pattern (Fig. 9B, D).

Close to the dolomitization fronts, the limestones may be crosscut by saddle dolomite veins, up to 6 mm thick and showing a bright red color under CL. The limestone-dolomite boundary usually is sharp, but locally it is characterized by the presence of diffused dolomite crystals (planar-e texture) within the limestone (Fig. 9C), scattering in a space of few millimeters, and displaying a bright red luminescence (Fig. 9D).

\section{Northern area}

Dolomite occurring in all the northern area outcrops have a homogeneous crystal size distribution, varying mostly from 40 to $100 \mu \mathrm{m}$ (Fig. 10A-D), although in some cases mosaics with finer (20-30 $\mu \mathrm{m})$ crystals were also observed. The mosaics are mostly unimodal, planar-s, with crystals showing a cloudy centre and straight extinction. These dolomites commonly retain features of the primary fabric, such as laminations, ghosts of bioclasts and brecciated facies (Fig. 10C, D).

In particular, dolomites of the Mount Marrone (Molise) display a planar-s mosaic of dolomite crystals of 40-80 $\mu \mathrm{m}$ (Fig. 10A) and are non-luminescent. Small (few millimeters long) dolomitecemented irregular vugs are present. They contain subeuhedral crystals of $200-400 \mu \mathrm{m}$ with straight to slightly undulose extinction, showing growth zones that alternate in CL between dull red and 
non-luminescence. Some of these crystals are merged into a fine-crystalline, dull red under CL, dolomite matrix.

The dolomites of Campagna and Mount Pierno present a planar-s texture with crystals having a mean size of 50-100 $\mu \mathrm{m}$ and showing a dull red luminescence (Fig. 10B). Dolomite veins, 80-100 $\mu \mathrm{m}$ thick and non-luminescent, were sometimes observed. Small vugs cemented by saddle dolomite crystals with a size of 300-400 $\mu \mathrm{m}$, showing under CL a dull red color with zonations, were observed occasionally (Fig. 10E, F). The chert nodules hosted in the dolomite contain euhedral rhombs of dolomite $(50-100 \mu \mathrm{m})$, and in some cases the nodules are almost completely replaced by dolomite (Fig. 10G, H).

At San Fele, the dolomites are coarsely crystalline. They show a planar-s mosaic with subeuhedral crystals of 100-200 $\mu \mathrm{m}$, having a dull red color under CL. These dolomites contain small dolomitecemented vugs displaying saddle crystals, which account only for minor volumes of dolomite.

\section{Features of southern area dolomites}

Petrographic observations allow distinguishing three main dolomite phases in the dolomite bodies in the southern area. These phases were called Dol1, Dol2 and Dol3, respectively. Dol1 corresponds to the gray dolomite recognized in the field, and is the volumetrically most abundant dolomite type and represents the massive dolomite that replaces the original limestone. It consists of a polymodal planar-s to nonplanar mosaic of anhedral and subeuhedral cloudy crystals showing two main size populations (40-80 $\mu \mathrm{m}$ and 150-200 $\mu \mathrm{m})$ and straight extinction (Fig. 11A). These crystals show a dull red, uniform and unzoned CL (Fig. 11B). Dol2 corresponds to most of the white void-filling dolomite recognized in the field, which is less abundant than Dol1, but occurs in all the outcrops. The lateral transition from Dol1 to Dol2 is characterized by an abrupt increase in the crystal size. Dol2 shows a nonplanar texture with saddle crystals having diameter ranging from $800 \mu \mathrm{m}$ up to several $\mathrm{mm}$, commonly elongated towards the cavities center, i.e. along the growth direction. They 
present sweeping extinction and crystal faces, cleavage planes and twins, all curved. The Dol2 crystals are uniformly cloudy, indicating the presence of inclusions homogeneously distributed within the crystals (Fig. 11C, E). These crystals have a dull red and uniform luminescence undistinguishable from that of Dol1 (Fig. 11D). The last generation of Dol2 crystals, that lines the cavities, displays a nonplanar-c texture and scimitar-like terminations. This generation may exhibit concentric zoning due to alternation of inclusion rich and inclusion poor zones (Fig. 11C, D). Typically, the last growth zone of the Dol2 crystals displays a dull orange CL (Fig. 11E, F). Dol2 commonly lines vuggy pores and fractures, and locally is followed by Dol3. This latter phase is translucent in hand sample, mainly consisting of nonplanar-c crystals, up to several mm across. These crystals grew in crystallographic continuity with Dol2 (Fig. 11E), and display a dark red to non-luminescent color without zonation under CL (Fig. 11F). In other cases, Dol3 constitutes the matrix of a micro-breccia, whose clasts are made up of angular fragments of Dol1 (100-400 $\mu \mathrm{m}$ in diameter). More commonly, Dol3 crystals fill thin fractures which cut through Dol1 and Dol2. In this case, no crystallographic continuity between Dol2 and Dol3 is observed (Fig. 11E, F). In few samples, a late phase of quartz cement was recognized as well. This is a polycrystalline quartz filling cavity centers, which remained open after the precipitation of Dol2 (Fig. 11G, H). Dolomite crystals at the boundary with the quartz cement display evidence of dissolution such as corroded borders.

\section{Subsurface dolomites}

The dolomite in the cuttings of Acerno 1 well displays several different textures: a nonplanar texture with anhedral crystals 20-30 $\mu \mathrm{m}$ in diameter (Fig. 12A), and a planar-s one with coarser subeuhedral crystals $(100-200 \mu \mathrm{m})$ with cloudy cores (Fig. 12B), both from dull red to nonluminescent under CL. Dolomite cements mostly in the upper dolomitized interval of the Acerno 1 well (between 295 and $472 \mathrm{~m}$ of depth) show nonplanar textures with crystal $>800 \mu \mathrm{m}$ with 
sweeping extinction, dull red color under CL, and commonly are twinned. Dolomite veins (200 $\mu \mathrm{m}$ thick), that are non-luminescent were also observed.

Dolomites in Monte Gargaruso 1 and Monte Foi 1 well cuttings both include similar texture. They consist of nonplanar to planar-s mosaics of different crystal sizes, mostly between $40-80 \mu \mathrm{m}$ and 100-200 $\mu \mathrm{m}$ (Fig. 12C). In CL, they present a dull red uniform color (Fig. 12D). Saddle dolomite cements (nonplanar-c) are very common in both wells, and show a dull red color indistinguishable from the CL of the matrix dolomite (Fig. 12E, F). These cements can be non-luminescent, whereas they display more commonly zonation of dull red bands alternating with darker bands (Fig. 12F). The fragments of chert contain scattered euhedral dolomite crystals (ranging between 60 and $80 \mu \mathrm{m}$ across), and dolomite veins, that display dull red CL.

\section{GEOCHEMISTRY}

$O$ and $C$ stable isotopes

Stable $\mathrm{C}$ and $\mathrm{O}$ isotopes from a total of 84 dolomite specimens included 21 analyses from the northern area (Molise, Campagna and San Fele), 34 from the southern area (from Pignola to the high Val d'Agri), 8 from Acerno 1, 8 from Monte Gargaruso 1, and 13 from Monte Foi 1. In the southern area, a separation between the replacive dolomite type (Dol1) and the void-filling dolomite type (Dol2+Dol3) was distinct, whereas it was not possible to sample powders of the vug-filling cements in the dolomites of the northern area, except for one sample from Campagna.

A $\delta^{18} \mathrm{O}$ vs. $\delta^{13} \mathrm{C}$ cross-plot illustrates two distinct clusters of values (Fig. 13). The first cluster includes dolomites from the outcrops of the northern area and from Acerno 1 well. They present $\delta^{18} \mathrm{O}$ values ranging from -2.5 and $1.0 \%$, with an overall mean of $-0.4 \%$, and $\delta^{13} \mathrm{C}$ values comprised between 2.3 and $3.9 \%$ with a mean of $3.1 \%$. The only dolomite cement sampled at Campagna (red circle in Fig. 13) shows a $\delta^{18} \mathrm{O}$ of $-1.4 \%$ and a $\delta^{13} \mathrm{C}$ of $2.74 \%$; both values fall in the lower range of the replacement dolomites from the northern area (red dots in Fig. 13). 
The second cluster consists of dolomites from the southern area and dolomites from the Monte Gargaruso 1 and Monte Foi 1 wells. All of these dolomites show a large spread of $\delta^{18} \mathrm{O}$ values, ranging from -11.8 and $-2.8 \%$, with most of the values falling between -8 and $-3.5 \%$ (mean value is $-5.6 \%$ ). $\delta^{13} \mathrm{C}$ ranges from 1.7 to $2.9 \%$ with a mean of $2.5 \%$.

Replacive (Dol1) and void-filling dolomites (Dol2 and Dol3) do not show significant differences in carbon and oxygen isotope ratios, as the corresponding $\delta^{13} \mathrm{C}$ and $\delta^{18} \mathrm{O}$ values fall in similar overlapping fields (Fig. 13). However, when comparing the replacive and void-filling types from individual samples, the void-filling dolomites show, with rare exceptions, $\delta^{18} \mathrm{O}$ lower (by 0.3 to 4.9 \%) compared to the replacive ones (see Table A in the online supplemental material).

\section{Minor element geochemistry}

Analysis of 52 dolomite specimens for minor and trace elements ( $\mathrm{Sr}, \mathrm{Mn}$ and $\mathrm{Fe}$ ) content revealed concentrations of $\mathrm{Sr}, \mathrm{Mn}$ and Fe (12 specimens from the northern area (Molise, Campagna, San Fele), 20 specimens from the southern area (Pignola to the high Val d'Agri), and 7, 2 and 11 cuttings specimens, from Acerno 1, Monte Gargaruso 1 and Monte Foi 1 wells, respectively). Similarly, elemental geochemistry between the replacive (Dol1) and the void-filling (Dol2 and Dol3) dolomite types among samples from the southern area showed that with two exceptions, the void-filling dolomite is slightly enriched in $\mathrm{Sr}$ (range of 41-136 ppm) compared to the replacive dolomite (range of 33-99 ppm). Mn content does not differ markedly from replacive and voidfilling dolomite types of the same sample, displaying a global range of 143-334 ppm, whereas the Fe concentration commonly is higher in the void-filling dolomite (range of 136-2286 ppm) than in the replacive dolomite (range of 34-1739 ppm), excepting four samples.

Cross-plots Mn vs. Sr, Fe vs. Sr and Mn vs. Fe (Fig. 14) reveal two different groups. Dolomites from the northern area, including those from Acerno 1 well, display lower Mn (between 26 and 234 ppm) and higher Sr (between 63 and $205 \mathrm{ppm}$ ) content than dolomites from the southern area, 
including those from Monte Gargaruso 1 and Monte Foi 1 wells (global range of 142-554 ppm and 31-136 ppm for the $\mathrm{Mn}$ and the Sr, respectively). Fe content does not vary markedly in the different localities and presents values ranging between 34 and 2949 ppm. Only samples from Monte Foi 1 well display a slightly higher Fe concentration (ranging between 86 and 5129 ppm).

\section{Sr isotopes}

Sr isotope ratios on 8 dolomite specimens included two from the northern area, four from the southern area (two of the replacive Dol1, and two of the void-filling Dol2 and Dol3) and two from Monte Gargaruso 1 well (Fig. 15). Dolomites from the northern area have ${ }^{87} \mathrm{Sr} /{ }^{86} \mathrm{Sr}$ ratios comprised between 0.707661 and 0.708038 , with mean at 0.707849 . Replacive dolomites from the southern area present ${ }^{87} \mathrm{Sr} /{ }^{86} \mathrm{Sr}$ ratios between 0.707908 and 0.708595 , with mean at 0.708251 , whereas voidfilling dolomites from the same area have ${ }^{87} \mathrm{Sr} /{ }^{86} \mathrm{Sr}$ ratios ranging between 0.708300 and 0.708814 , with mean at $0.708557 .{ }^{87} \mathrm{Sr} /{ }^{86} \mathrm{Sr}$ ratios for dolomites from Monte Gargaruso 1 well range between 0.707831 and 0.708274 , and have a mean of 0.708052 .

\section{Fluid inclusions from dolomites of southern area}

Fluid inclusions microthermometry was performed only on saddle dolomite crystals (Dol2) of nine samples from the southern area, as the gray replacive dolomites from both northern and southern areas host inclusions too small $(<2 \mu \mathrm{m})$ for analysis. Moreover, no measurable inclusions were found in saddle crystals filling vugs in samples of the northern area (Fig. 10E).

Dol2 holds both small $(<2 \mu \mathrm{m})$ monophase (liquid) and biphase (always liquid and vapor) inclusions. The latter are mostly $5-10 \mu \mathrm{m}$ in length with shape mainly from irregular to crystallographically controlled, rectangular and elongate (Table 1; see also Table B of the online supplemental material). Biphase inclusions show consistent vapor:liquid ratio, with the bubbles most commonly making up $\sim 6-7 \%$ of the inclusion. Fluid inclusions were distinguished based on 
their occurrence within the host crystal (Fig. 16A), i.e. in the crystal cores, along growth zones, and along crystal edges (generally fluid inclusion poor). They all share the typical features of primary fluid inclusions. Indeed, their distribution in the crystals is controlled by growth zonations and their shape is controlled commonly by crystallographic planes, i.e. one or more sides of the inclusions are parallel to crystal borders or cleavage planes (Fig. 16B). Pseudosecondary inclusions were observed rarely, aligned along trails which do not propagate through the whole crystal. Fluid inclusions of indeterminate origin occur isolated or in patchy concentrations (i.e. not controlled by crystal growth features) only in sample TG40B, but display petrographic features (i.e. shape and size) and microthermometry results comparable to those from the undoubtedly primary inclusions.

Microthermometry results of the studied aqueous biphase (liquid and vapor) fluid inclusions (Table 1; see also Table B of the online supplemental material) reveal salinities, calculated from final Tm using the equation of Bodnar (1993) in the $\mathrm{H}_{2} \mathrm{O}-\mathrm{NaCl}$ system, between 1.9 and $6.4 \mathrm{wt} \% \mathrm{NaCl}$ eq. and show a mean at $3.7 \mathrm{wt} \% \mathrm{NaCl}$ eq. (for details see Gabellone et al. 2013). Homogenization temperatures within each FIA are fairly consistent within a range of $\pm 5^{\circ} \mathrm{C}$, while temperatures for different FIA vary over $\pm 15{ }^{\circ} \mathrm{C}$. A clear temperature trend from the core towards the edge of the crystals was not observed. Overall the measured Th from various samples range mostly between 70 and $120^{\circ} \mathrm{C}$ and display a mode at $95 \pm 10{ }^{\circ} \mathrm{C}$. Slightly higher $\left(\sim 20^{\circ} \mathrm{C}\right)$ temperatures were recorded in samples from an area north-west of Pignola-high Val d'Agri (i.e. Vietri di Potenza and TitoSatriano; Fig. 5).

Homogenization temperatures for the samples of Monte Gargaruso 1 well are not reported, as these samples showed a behavior suggesting clear thermal re-equilibration and/or leakage, probably due to overheating during drilling operation (for details see Gabellone et al. 2013).

\section{DISCUSSION}

Northern vs. southern area dolomites 
Field survey and examination of stratigraphic well logs penetrating the Lagonegro succession have confirmed that dolomitization of the Triassic cherty limestones from the Calcari con selce Formation is indeed a regional-scale event. Although dolomitization is not pervasive, dolomites occur in both proximal and intermediate basinal facies. However, petrographic characteristics and geochemical data indicate that the succession in the northern area (Molise, Campagna and San FeleMount Pierno) and southern area (from Pignola to high Val d'Agri) underwent different dolomitization processes.

Dolomites of the northern area preserve many sedimentary features of the precursor limestones and are mostly medium crystalline. They display planar-s textures and unimodal crystal size and are dull red to non-luminescent under CL (Fig. 10A-D). Similar petrographic features are displayed by dolomites from the Acerno 1 well cuttings, which was drilled also in the northern area. Dolomitization under early diagenetic conditions and from low temperature fluids are indicated for the northern area dolomites by oxygen and strontium isotopes analysis. About half of the $\delta^{18} \mathrm{O}$ values fall in the Upper Triassic seawater isotopic range (Veizer et al. 1999; Korte et al. 2005), whereas the other half of the values is enriched slightly $(+1-2 \%)$ in ${ }^{18} \mathrm{O}$ with respect to the seawater values. Dolomites from the Norian shallow-water successions of the Apenninic platform present $\delta^{18} \mathrm{O}$ values $(0.8-2.6 \%$; Iannace 1991$)$ with a Norian marine signature and therefore, are slightly enriched in ${ }^{18} \mathrm{O}$ relative to the northern dolomites from this study (Fig. 13). On the other hand, oxygen isotope values of dolomites from Norian build-ups and slope facies of the same platform (-2.5 to $0.5 \%$; Laiena et al. 2011) overlap those of the Lagonegro basinal dolomites of northern area (Fig. 13).

The $\delta^{13} \mathrm{C}$ signature of dolomites from the northern area is very uniform and varies between +2 and +4\%, values that are all consistent with Upper Triassic seawater values, reflecting the initial composition of the precursor carbonate, as carbon in pore fluids is contained as dissolved carbonate 
and may be buffered by the host rock. $\delta^{13} \mathrm{C}$ values are also in agreement with carbon isotopes values displayed by Norian Apenninic platform dolomites (2 - 3.8 \%; Iannace 1991; Fig. 13).

$\mathrm{Sr}$ isotopes ratios of dolomites from the northern area are consistent with Upper Triassic seawater (0.7076 - 0.7080; McArthur and Howarth 2004) and comparable to those measured in the undolomitized limestone of the Calcari con selce Formation at Pignola (black ellipse in Fig. 15; Iannace et al. 2012).

The Sr concentration (ranging from 60 to $200 \mathrm{ppm}$ ) of dolomites in the northern area is also in agreement with an early replacement of a marine calcite precursor (Warren 2000, and references therein). The low Fe and Mn content, which characterizes these dolomites, is a feature typical of oxidizing fluids, which may be responsible for early, near surface dolomitization (Land 1980; Machel et al. 1991).

Dolomites outcropping in the southern area, from Pignola to high Val d'Agri, and those in the Monte Gargaruso 1 and Monte Foi 1 wells, present features typical of a late burial origin, such as abundant void-filling saddle dolomite crystals and nonplanar texture of the replacive type (Radke and Mathis 1980; Gregg and Sibley 1984; Taylor and Sibley 1986).

The possibility that the dolomite of the southern area results from the neomorphism of the early dolomite from the northern area could be suggested by the replacive dolomite (Dol1) texture which commonly displays two main population sizes. Indeed, according to Machel (2004), a polymodal crystal size distribution could be due to either recrystallization or textural heterogeneities in the precursor limestone prior to dolomitization. Examples of the first possibility have been discussed in literature (e.g. Roure et al. 2005; Morad et al. 2012), while other field studies have provided documentation of dolomite textural heterogeneities controlled by former sedimentary features (e.g. Gasparrini et al. 2006; Iannace et al. 2013). In the studied case from the Lagonegro basin, the hypothesis linked to the textural heterogeneities is unlikely as the precursor limestones were quite homogeneous mudstones and wackestones. However, even the hypothesis of neomorphism of the 
early diagenetic dolomite is unlikely. Indeed, in the vicinity of the southern-type dolomites, rock masses displaying features typical of the northern-type dolomites were never observed. Moreover, relics of undolomitized limestones, close to the boundary with the southern-type dolomite bodies, contain many scattered dolomite crystals, indicating that the southern dolomites replaced a precursor limestone, and excluding the possibility of a neomorphic recrystallization of an earlier dolomite. The most possible explanation for the observed polymodal texture is the recrystallization of the southern dolomite (Dol1) itself which affected in an irregular and discontinuous manner the replacive dolomite rock volume during burial.

Most dolomites of the southern area are quite depleted in ${ }^{18} \mathrm{O}$ (Fig. 13) relative to syn-depositional seawater values (i.e. Upper Triassic; Veizer et al. 1999; Korte et al. 2005), displaying an isotopic trend typical of burial dolomites (Morse and Mackenzie 1990; Tucker and Wright 1990). In most samples, the void-filling dolomite type is slightly more depleted in ${ }^{18} \mathrm{O}$ respect to the corresponding replacive dolomite type (see Table $\mathrm{A}$ in the online supplemental material). This depletion, a commonly observed pattern in zebra-dolomites, could be due to changing isotopic composition of the dolomitizing fluids over time. Alternatively, a higher water/rock ratio and/or a higher temperature for the parent fluid of the void-filling dolomites could have accounted for the same effect. In either case, the replacive (Dol1) and the void-filling (Dol2 and Dol3) dolomites were most likely produced by the same fluid in evolution, as suggested by the same uniform dull red color in cathodoluminescence (Fig. 11B, D).

Values for $\delta^{13} \mathrm{C}$ are less dispersed and reflect the values of the host limestone (black ellipse in Fig. 13; data from Iannace et al. 2012). Sr isotopes data indicate a slightly more radiogenic nature for dolomite fluids from the southern area compared to the precursor limestones (black ellipse in Fig. 15; Iannace et al. 2012) and to the dolomites from the northern area.

Trace elements content also suggests a late origin for the dolomites from the southern area. Fe and Mn contents are higher than in early dolomites from the northern area. Since most subsurface fluids 
are reducing, late burial dolomites are generally characterized by high Fe and Mn content (Land 1980; Morrow 1982; Barnaby and Read 1992; Gasparrini et al. 2006). Sr concentration on the contrary is very low (a few tens of ppm), in both the replacive and the void-filling dolomites from the southern area. A similar low Sr concentration has been reported by many authors for other late burial dolomites (Mattes and Mountjoy 1980; Barnaby and Read 1992; Montañez 1994; Gasparrini et al. 2006).

Minimum trapping temperatures estimated from fluid inclusions analysis on the void-filling dolomites display a mode at $95 \pm 10{ }^{\circ} \mathrm{C}$ (see Gabellone et al. 2013 for details) and represent the strongest evidence of a late, high temperature origin for all the dolomites of the southern area. Slightly higher $\left(\sim 20^{\circ} \mathrm{C}\right)$ temperatures, recorded in samples from Vietri di Potenza and Tito-Satriano area (north-west of Pignola-high Val d'Agri; Fig. 5) possibly are due to a greater tectonic loading undergone by this area, that experienced deeper burial during dolomitization in respect with the Pignola-high Val d'Agri area (Gabellone et al. 2013).

\section{Early dolomitization event}

Petrographic and geochemical data allow interpretation of the Upper Triassic basinal dolomites of the Lagonegro succession, outcropping in Molise, Campagna and Mount Pierno-San Fele (northern area), as the result of a replacement by modified seawater at ambient temperature in an oxidizing environment. It is therefore necessary to look for a mechanism of massive flux of marine waters leading to a pervasive dolomitization of the basinal limestones in the very shallow, oxidizing burial environment, possibly soon after sedimentation. Among the several models of low-temperature, large scale dolomitization (Machel 2004), possible candidates are the downward reflux of platform seawater, the Kohout convection of oceanic waters and the compaction-driven expulsion of formation waters. 
Processes of seawater reflux through carbonate platforms were first suggested by Adams and Rhodes (1960) to explain dolomitization of Permian carbonates in west Texas, which are stratigraphically associated with platform interior evaporites. The density contrast between the strongly evaporated seawater over the platform and the normal seawater of nearby ocean was presented as the driving mechanism of fluid flow. However, it has been physically demonstrated that the absence of evaporites does not preclude reflux and that even a weak density contrast may be sufficient to start the process (Simms 1984; Whitaker and Smart 1990; Melim and Scholle 2002). Analogous studies and numerical modeling have demonstrated that reflux processes could be active along several hundred meters and even beyond 1 kilometer of depth (Jones et al. 2000; Jones and Xiao 2005; Lonnee and Machel 2006). Dolomitization by reflux generally affects only very limited portion of the upper slope (Montañez and Read 1992; Melim and Sholle 2002; Coniglio et al. 2003; Rivers et al. 2012).

During the deposition of the Calcari con selce Formation the Lagonegro basin was surrounded to the west, north and east, by a wide, shallow platform shelf where early dolomitization of neritic carbonates and evaporite deposition were active (Fig. 2). Thick dolomite successions deposited on the Apenninic platform, whereas evaporites and carbonates formed on the Apulia platform. Actually, in the Norian of the entire alpine and peri-mediterranean carbonate platforms, early dolomitization of thick sections was a very common phenomenon (Iannace and Frisia 1994; Meister et al. 2013). These thick dolomite formations are classically referred to as Hauptdolomit, Main Dolomite or Dolomia Principale. Dolomitization affected not only the lagoonal and peritidal facies but also the bioconstructed marginal facies (Iannace and Zamparelli 2002) as well as the basinal intraplatform organic-rich sediments (Cirilli et al. 1999).

Iannace and Frisia (1994) attributed the Norian large-scale dolomitization event to specific palaeoceanographic, tectonic and climatic conditions in the Tethyan region, including warm and arid climate, and restricted oceanographic circulation, which promoted both hypersalinity and a 
stratified water column. These conditions ended by Rhaetian time, following a major climatic change. Balog et al. (1999) also recognized a strong climate control on dolomitization in the Hungarian Late Triassic platform. In these peritidal domains, and under such an arid climate, penecontemporaneous dolomites were formed most likely through the density-driven circulation of hypersaline brines (Frisia 1994; Iannace and Frisia 1994; Haas and Demény 2002).

The long-lasting presence of concentrated seawater on the shelves of the Apenninic platform makes their reflux towards the slope of the nearby Lagonegro basin an extremely likely process. Thus, it could be expected that descending fluids had a strong dolomitization potential and were able to replace the calcareous mud of the Lagonegro succession, even far away from the edge of the platform (up to $\sim 40 \mathrm{~km}$ ). Its effectiveness as a dolomitization process has been proposed by Passeri et al. (2005), based on geological data from the literature, for all the dolomites of the Lagonegro succession. The presented data support this interpretation, but only for the northern dolomite bodies. The oxygen and carbon isotope signatures of the northern area dolomites are slightly lighter than those of Norian dolomites of the Apenninic platform (Iannace et al. 2011; Fig. 13) and are comparable to those of other Norian dolomites (Frisia 1994; Ogorelec et al. 1999; Haas and Demény 2002). Moreover, they are in good agreement with signatures from recent dolomites, interpreted to be of marine or evaporitic origin (Warren 2000, and references therein).

In a water a dominated system that has come to equilibrium, $\delta^{18} \mathrm{O}$ of dolomites directly precipitating from seawater at ambient surface temperature is characterized by an increase of about $+2.7 \%$ oDB with respect to coeval seawater values (Land 1980, 1985; Vasconcelos et al. 2005). The oxygen signatures obtained for the northern area dolomites are slightly more depleted in ${ }^{18} \mathrm{O}$ with respect to Upper Triassic marine signatures. This signature could indicate the presence of a rock-dominated system where equilibrium with seawater has not been attained. Alternatively, the seawater could have been slightly warmer than present-day surface temperatures to achieve a similar effect. Another possibility is the downdip reduction of reflux dolomitizing brine saturations, as observed in 
many case histories (Saller and Henderson 1998; Wahlman 2010). Finally, another hypothesis could be the overprint effect by later warm basinal fluids. This latter case is most likely to have occurred as saddle dolomite has been observed in small vugs in the dolomites of the northern area (Fig. 10E). These saddle dolomite crystals were likely the result of a later dolomitization event. The only geochemical data available for these cements $\left(\delta^{18} \mathrm{O}\right.$ of $-1.4 \%$ ) indicates that the fluid differs from the parent fluid of the southern area dolomites. However, the lack of further data on the saddle cements from the northern area hinders the understanding of their origin.

The suggested reflux model is in agreement with the presence of early dolomites exclusively in the northern area and with the general paleogeography of the Lagonegro basin (Fig. 2). In fact, according to regional facies distribution of the Triassic and Jurassic of the Lagonegro succession, Scandone (1967) and Miconnet (1988) interpreted the northern area to have been deposited closer to the Apenninic platform. Due to severe tectonic shortening, large part of the Lagonegro sediments are now buried beneath the tectonic pile of the Apennine and a well-constrained basin reconstruction is not possible. However, all the paleogeographic reconstructions now agree in depicting a Lagonegro basin closed to the north (Fig. 2). This interpretation suggests that the northern outcrops were closer to the platform, even though the true distance between the dolomitized facies of the northern area and the edge of the platform is not known. On the contrary, the southern outcrops were originally more distal and at present occur close to the Apenninic platform outcrops as a result of severe west-east shortening due to compressional phases of the southern Apennines fold and thrust belt emplacement (Mazzoli and Helman 1994, and references therein).

Alternative dolomitization models fitting the geochemical signature of Norian marine fluids are the Kohout convection of oceanic waters (Kohout 1965) and the compaction-driven expulsion of formation waters (Illing 1959). The Kohout convection model implies a relatively steep profile of the platform flanking a basin and leads to the dolomitization of platform and slope beds. This model 
has been applied to the Late Triassic-Early Jurassic "dolomite breccias" of the Fanusi Formation of Sicily (Italy; Dewever 2008). A higher heat flux has been used to explain the geothermal heating of dolomitizing fluids of the Fanusi Formation Such an anomalous heat flux may be expected in the Central Mediterranean Sea during the Triassic and Jurassic, due to the break-up of Pangea and the opening of numerous rift systems in the area (Stampfli and Borel 2002). The Fanusi Formation dolomites formed in a steep slope setting (Catalano and D'Argenio 1982). The facies of the dolomitized Calcari con selce Formation from the study area are not indicative, however, of a comparable depositional setting.

A flow of thermally-driven fluids has been suggested as well by Iannace et al. (2011) to explain the formation of dolomites in Rhaetian and Jurassic platforms and intraplatform basins of the southern Apennines, right above the Norian platform dolomites. According to these authors, a large-scale flux of seawater was driven by thermal anomalies related to the Late Jurassic Tethyan spreading, as supported also by Sr-isotopes. The Lagonegro dolomites from the northern area display Sr-isotope data indicating a Triassic marine source. Moreover, no tectonics was active during the Jurassic in the Lagonegro basin (Schettino and Turco 2011).

A late, large scale circulation of marine fluids can be driven also by compaction and then focused by faults. Such a model has been invoked by Murgia et al. (2004) to explain dolomites in the Jurassic platform to slope sediments of Central Apennine area affected by Jurassic synsedimentary faulting. Such a fluid circulation may have been effective during the Lagonegro basin evolution. Faulting was certainly active at the boundary between the platform and the basin during the Triassic (Woods 1981; Mazzoli et al. 1992) and marine fluids could have been expulsed from the underlying siliciclastic succession (Monte Facito Fm). According to such a scenario the Sr-isotope signature of the marine fluids should have been modified because of the prolonged water-rock interaction in a silicate-rich aquifer. However, this conceptual model represents the only possible alternative to the proposed reflux model. 
The reflux model has been applied frequently to explain massive dolomitization affecting ancient carbonates platforms (Adams and Rhodes 1960; Clark 1980; Moore et al. 1988; Warren 2000; Qing et al. 2001; Jiang et al. 2013), and has been documented as well in modern platform settings, although in the latter case it accounts only for small amount of dolomite (Deffeyes et al. 1965). By contrast, reflux occurring in slope to basin sediments has been reported in a few cases only. In the Upper Permian Zechstein carbonates of northwest Europe, refluxing brines, generated in a hot and arid climate and associated with deposition of overlying evaporites, were capable to reach and dolomitize the slope facies (Clark 1980). Massive basinal dolomites were formed in the Middle Devonian Ratner laminite of the southern Saskatchewan (Canada) by reflux of downward evaporitic brines, which locally migrated through fractures (Fu et al. 2006). Meso-haline reflux is currently documented in the upper slope of the southern Australian Continental margin, whereby the sediments result partially dolomitized at water depth of around 200-600 m (Rivers et al. 2012). Here the main factor promoting dolomitization is not the climate, but rather the low carbonate saturation level of the system, that inhibits the precipitation of the kinetically more favored phases in normal seawater (aragonite and calcite).

An early reflux process, which in peculiar climatic, oceanographic, or fluid saturation conditions can reach the slope and the proximal basin, is of particular interest for hydrocarbon exploration. In fact reflux dolomites are generally good reservoirs and some case-studies of reflux predict highest porosity in the distal part of the fluid flow pathway (Lucia and Major 1994; Sun 1995; Saller and Handerson 1998).

In geological contexts different than the Upper Triassic Lagonegro basin, but under similar climatic conditions, comparable dolomitization patterns could be expected to occur not only in platform settings but also in slope and proximal basinal facies.

\section{Late burial dolomitization event}


Dolomites from the Calcari con selce Fm., situated between Pignola and the high Val d'Agri (southern area), show strong evidence of a burial origin by warm and reducing fluids (Fig. 11 and 13). Microthermometric data indicates dolomite formation at minimum temperatures comprised between 70 and $120{ }^{\circ} \mathrm{C}$, and fluid salinities ranging between 1.9 and $6.4 \mathrm{wt} \% \mathrm{NaCl}$ eq. with mean at 3.7 wt $\% \mathrm{NaCl}$ eq.

These zebra dolomites were studied by Gabellone et al. (2013) along a transect within the Pignolahigh Val d'Agri area. The crosscutting relationships of these dolomites with pressure solution cleavage, which developed during the first compression phase of the southern Apennines (Mazzoli et al. 2001), indicate that dolomitization occurred after this deformational stage. Indeed the spacing of the cleavage remains constant across the dolomitization front (Fig. 7A). This would not be the case if dolomite formation occurred prior to cleavage development due to the differing mechanical properties of limestone and dolomite.

Based on structural observations, Gabellone et al. (2013) recognized syn-deformational genesis of the dolomites under the action of overpressured fluids. This interpretation is further supported by the occurrence of the brecciated fabrics observed locally (Fig. 7E, F), which possibly formed by hydraulic fracturing (Phillips 1972; Sibson 1990).

Comparing the calculated maximum trapping temperatures of these dolomites $\left(148-168{ }^{\circ} \mathrm{C}\right)$ with the available thermometric data from the southern Apennines (Corrado et al. 2005; Mazzoli et al. 2008) suggests that dolomites formed during the second phase of deformation, in early stages of exhumation, between 5 and $4 \mathrm{Ma}$ and under 3-4 $\mathrm{km}$ of burial. The dolomitization model is squeegee fluid expulsion (Oliver 1986) from a major thrust zone. Gabellone et al. (2013) identified the modified marine pore-waters from the décollement horizon of the southern Apennines belt (melange units) as the more probable fluid source for the Lagonegro dolomites.

It is still an open question why the zebra dolomites occurring in outcrops and subsurface of the southern area (from Pignola to the high Val d'Agri), did not form either in the northern Lagonegro 
units, where mostly early dolomites were recognized, or further to the south (Lagonegro village area), where the Calcari con selce Formation remained undolomitized. It could be speculated that the thrust faults, which acted as fluid conduits, activated during the second deformation stage, did not intercept the fluid sources to the north and to the south of the Pignola-high Val d'Agri area, as if the thrust faults reached different depths in different areas of the basin.

\section{CONCLUSIONS}

The Lagonegro basinal succession of the southern Apennines fold and thrust belt includes two different massive events of dolomitization. Field survey and analyses of cuttings from oil wells, integrated with petrographic and geochemical studies, allowed distinction between two areas displaying two different styles of dolomitization.

Dolomites documented in the northernmost area (Molise, Campagna and San Fele-Mount Pierno) is early diagenetic in origin and possibly related to a large reflux of marine or marine-derived fluids from the Apenninic carbonate platform margins towards the proximal basin. This relatively uncommon event of early dolomitization at the margin of a large pelagic basin is possibly a further expression of the large scale dolomitization phenomena which characterized the Norian carbonates as a consequence of peculiar climatic and paleoceanographic conditions, such as warm and arid climate and restricted oceanographic circulation.

The Lagonegro carbonates of the southern area (from Pignola to the high Val d'Agri) were more distal from the Apenninic platform margin and were not reached by refluxing brines. Dolomites observed in this area are the product of a late burial dolomitization related to the activation of a major thrust zone during the southern Apennines fold and thrust belt evolution.

The case-study represents an uncommon example of basinal carbonates that have undergone multiple events of massive dolomitization originated from early diagenesis to late burial alteration. In many geological reservoirs, the dolomitization process is well recognized to have a potentially 
important impact on reservoir quality. In this example, reflux dolomitization does not appear to have been restricted only to the platform but has also affected slope and basinal facies. This suggests that under certain climatic and oceanographic conditions, the reflux mechanism may have further-reaching effects on reservoir quality than previously recognized.

\section{ACKNOWLEDGEMENTS}

We are grateful to Eni S.p.a that allowed us to observe the stratigraphic logs of the Val d'Agri explorations wells and to sample the cuttings from the Acerno 1 and Monte Gargaruso 1 wells. We thank as well Shell Italia E\&P for giving us cuttings from the Monte Foi 1 well.

We acknowledge Dr. Dieter Buhl, for performing the geochemical analyses at the Isotopen-labor of the Institut für Geologie, Mineralogie und Geophysik of the Ruhr University (Bochum, Germany).

We thank Miles Frazer and Graham Griffiths who improved the English form of the manuscript. The Editor Gene Rankey, the Associate Editor Leslie Melim, Jay Gregg, and an anonymous reviewer are acknowledged for their valuable and constructive comments.

\section{REFERENCES}

ADAMS, J.E. AND RHODES, M.L., 1960, Dolomitization by seepage reflux: American Association of Petroleum Geologists Bulletin, v. 44, p. 1912-1920.

Aldega, L., Cello, G., Corrado, S., Cuadros, J., Di Leo, P., Giampaolo, C., Invernizzi, C., Martino, C., Mazzoli, S., Schiattarella, M., Zattin, M., And Zuffa, G., 2003, Tectonosedimentary evolution of the Southern Apennines (Italy): thermal constraints and modelling: Atti Ticinensi di Scienze della Terra - ser. spec., v. 9, p. 135-140. 
Aldega, L., Corrado, S., Di Leo, P., Giampaolo, C., Invernizzi, C., Martino, C., Mazzoli, S., Schiattarella, M. And ZatTin, M., 2005, The Southern Apennines case history: thermal constraints and reconstruction of tectonic and sedimentary burials: Atti Ticinensi di Scienze della Terra, v. 10, p. 45-53.

BAKKER, R.J. AND DIAMOND, L.W., 2006, Estimation of volume fractions of liquid and vapor phases in fluid inclusions, and definition of inclusion shapes: American Mineralogist, v. 91, p. 635657.

BALOG, A., READ, L.F. AND HAAs, J., 1999, Climate-controlled early dolomite, late Triassic cyclic platform carbonates, Hungary: Journal of Sedimentary Research, v. 69, p. 267-282.

BARNABY, R.J. AND READ, J.F., 1992, Dolomitization of a carbonate platform during late burial: Lower to Middle Cambrian Shady Dolomite, Virginia Appalachians: Journal of Sedimentary Petrology, v. 62, p. 1023-1043.

BEALES, F.W. AND HARDY, J.L., 1980, Criteria for the recognition of diverse dolomite types with an emphasis on studies on host rocks for Mississippi Valley-Type ore deposits: SEPM Special Publication, v. 28, p. 197-213.

Bertinelli, A., CiarapicA, G. And Passeri, L., 2002, The Late Triassic cherty dolostones of Mt. Marrone (Mainarde range) as a part of the Molise Basin: Bollettino della Società Geologica Italiana, Special Volume, v. 1(2), p.481-487.

BODNAR, R.J., 1993, Revised equation and table for determining the freezing point depression of $\mathrm{H}_{2} \mathrm{O}-\mathrm{NaCl}$ solutions: Geochimica et Cosmochimica Acta, v. 57, p. 683-684.

Butler, R.W.H., Mazzoli, S., CorRado, S. et al., 2004, Applying thickskinned tectonic models to the Apennine thrust belt of Italy; limitations and implications in McClay, K.R. et al., eds., Thrust Tectonics and Hydrocarbon Systems, American Association of Petroleum Geologists Memoirs, v. 82, p. 647-667. 
Catalano, R. And D'Argenio, B., 1982, Guida alla geologia della Sicilia Occidentale: Società geologica italiana, guide geologia regionale, $189 \mathrm{p}$.

Cervato, C., 1990, Hydrothermal dolomitization of Jurassic-Cretaceous limestones in the southern Alps (Italy): Relation to tectonics and volcanism: Geology, v. 18(5), p. 458-461.

CIARAPICA, G., 2007, Regional and global changes around the Triassic-Jurassic boundary reflected in the late Norian-Hettangian history of the Apennine basin: Palaeogeography, Palaeoclimatology, Palaeoecology, v. 244, p. 34-51.

Ciarapica, G., Cirilli, S., Panzanelli Fratoni, R., Passeri, L. And Zaninetti, L., 1990, The Monte Facito Formation (Southern Apennines): Bollettino della Società Geologica Italiana, v. 109(1), p. 135-142.

Cirilli, S., IAnNace, A., Jadoul, F., And Zamparelli, V., 1999, Microbial-serpulid buildups in the Norian-Rhaetian of the Western Mediterranean area: ecological response of shelf margin communities to stressed environments: Terra Nova, v. 11, p. 195-202.

Clark, D.N., 1980, The diagenesis of Zechstein carbonate sediments in , Fuchtbauer, H. and Peryt, T., eds., The Zechstein Basin with emphasis on carbonate sequences. Contributions in Sedimentology, v. 9, p. 167-203.

Coniglio, M. AND James, N.P., 1988, Dolomitization of deep-water sediments, Cow Head Group (Cambro-Ordovician), western Newfoundland: Journal of Sedimentary Petrology, v. 58, p. $1032-1045$.

CONIGLIO, M., ZHENG, Q. AND CARTER, T.R., 2003, Dolomitization and recrystallization of Middle Silurian Reefs, Michigan Basin, southwestern Ontario: Bulletin of Canadian Petroleum Geology, v. 51, p. 177-199. 
CorRAdo, S., INVERNIZZI, C. AND MAZzOLI, S., 2002, Tectonic burial and exhumation in a foreland fold and thrust belt: The Monte Alpi case history (Southern Apennines, Italy): Geodinamica Acta, v. 15(3), p. 159-177.

Corrado, S., Aldega, L., Di Leo, P., Giampaolo, C., Invernizzi, C., Mazzoli, S., And Zattin, M., 2005, Thermal maturity of the axial zone of the southern Apennines fold-and-thrust belt (Italy) from multiple organic and inorganic indicators: Terra Nova, v. 17, p. 56-65.

DefFeYes, K.S., LuCIA, F.J., AND WeYL, P.K., 1965, Dolomitization of recent and Plio-Pleistocene sediments by marine evaporite waters on Bonaire, Netherlands Antilles in Pray, L.C., Murray, R.C., eds., Dolomitization and Limestone Diagenesis, SEPM Special Publication, v. 13, p. $71-88$.

DEwEVER, B.,2008, Diagenesis and fluid flow in the Sicilian fold-and-thrust belt. PhD Thesis, KULeuven, $184 \mathrm{p}$.

DiCKSON, J.A.D., 1966, Carbonate identification and genesis as revealed by staining: Journal of Sedimentary Petrology, v. 36(2), p. 491-505.

FINETTI, I., 2005, The Calabrian arc and subducting Ionian slab from new CROP seismic data in Finetti, I., ed., CROP Project: Deep Seismic Exploration of the Central Mediterranean and Italy, p. 393-412.

FRISIA, S., 1994, Mechanisms of complete dolomitization in a carbonate shelf: comparison between the Norian Dolomia Principale (Italy) and the Holocene of Abu Dhabi Sabkha in Purser, B., Tucker, M. and Zenger, D., eds., Dolomites, IAS Special Publication, v. 21, p. 55-74.

FU, Q., QING, H. AND BERGMAN, K.M., 2006, Early dolomitization and recrystallization of carbonate in an evaporite basin: the Middle Devonian Ratner laminite in southern Saskatchewan, Canada: Journal of the Geological Society, v. 163, p. 937-948. 
Gabellone, T., Gasparrini, M., IAnnace, A., Invernizzi, C., Mazzoli, M. And D’Antonio, M., 2013, Fluid channeling along thrust zones: the Lagonegro case history, southern Apennines, Italy: Geofluids, v. 13, p. 140-158.

Gasparrini, M., BeChStAD, T., Boni, M., 2006, Massive hydrothermal dolomites in the southwestern Cantabrian Zone (Spain) and their relation to the Late Variscan evolution: Marine and Petroleum Geology, v. 23 (5), p. 543-568.

GoldsteIn, R.H. AND REYNOLDS, T.J., 1994, Systematics of fluid inclusions in diagenetic minerals. SEPM Short Course, v. 31, Tulsa, Oklahoma, 199 p.

GREGG, J.M. AND SIBLEY, D.F., 1984, Epigenetic dolomitization and the origin of xenotopic dolomite texture: Journal of Sedimentary Petrology, v. 54, p. 908-931.

HAAS, J. AND DEMÉNY, A., 2002, Early dolomitization of Late Triassic platform carbonates in the Transdanubian Range (Hungary): Sedimentary Geology, v. 151, p. 225-242.

IANNACE, A., 1991, Ambienti deposizionali e processi diagenetici in successioni di piattaforma carbonatica del Trias superiore nei Monti Lattari e Picentini (Salerno). PhD Thesis, University of Napoli, Italy.

IANNACE, A. AND FRISIA, S., 1994, Changing dolomitization styles from Norian to Rhaetian in the southern Tethys realm in Purser, B., Tucker, M. and Zenger, D., eds., Dolomites, IAS Special Publication, v. 21, p. 75-89.

IANNACE, A. AND ZAMPARELLI, V., 2002, Upper Triassic platform margin biofacies and the paleogeography of Southern Apennines: Palaeogeography, Palaeoclimatology, Palaeoecology, v. 179 , p. $1-18$. 
IAnNaCe, A., CAPuAno, M., Galluccio, L., 2011, "Dolomites and dolomites” in Mesozoic platform carbonates of the Southern Apennines: Geometric distribution, petrography and geochemistry: Palaeogeography, Palaeoclimatology, Palaeoecology, v. 310, p. 324-339.

IANNACE, A., GASPARrini, M., GABELlone, T., AND MAZzOLI, S., 2012, Late dolomitization in basinal limestones of the southern Apennines fold and thrust belt (Italy): Oil \& Gas Science and Technology - Revue d'IFP Energies nouvelles, v. 67, p. 59-75.

IAnNaCe, A., FriJia, G., GAlluccio, L., PARENTE, M., 2013, Facies and early dolomitization in Upper Albian shallow-water carbonates of the southern Apennines (Italy): paleotectonic and paleoclimatic implications: Facies, p. 1-26.

ILlING, L.V., 1959, Deposition and diagenesis of some Upper Palaeozoic carbonate sediments in western Canada: 5th World Petroleum Congress, New York, p. 23-52.JONES, G.D AND XIAO, Y., 2005, Dolomitization, anhydrite cementation and porosity evolution in a reflux system: Insights from reactive transport models: American Association of Petroleum Geologists Bulletin, v. 89, p. 577-601.

JiAnG, L., CAI, C. F., Worden, R. H., LI, K.K. And XiAnG, L., 2013, Reflux dolomitization of the Upper Permian Changxing Formation and the Lower Triassic Feixianguan Formation, NE Sichuan Basin, China: Geofluids, v. 13, p. 232-245.

Jones, G., Whitaker, F., SMART, P.L., AND SANFORD, W., 2000, Numerical modelling of geothermal and reflux circulation in Enewetak Atoll: Implications for dolomitization: Journal of Geochemical Exploration, v. 69-70, p. 71-75.

Kelts, K.R. And MCKenZIE, J.A., 1982, Diagenetic dolomite formation in Quaternary anoxic diatomaceous muds of Deep Sea Drilling Project Leg 64, Gulf of California: Initial Report Deep Sea Drill. Project, v. 64(2), p. 553-569. 
KoHOUT, F.A., 1965, A hypothesis concerning cyclic flow of salt water related to geothermal heating in the Floridan aquifer: New York Academy of Sciences Transactions, ser. 2, v. 28(2), p. 249271.

Korte, C., Kozur, H.W. AND VeIzer, J., 2005, $\delta^{13} \mathrm{C}$ and $\delta^{18} \mathrm{O}$ values of Triassic brachiopods and carbonate rocks as proxies for coeval seawater and palaeotemperature: Palaeogeography, Palaeoclimatology, Palaeoecology, v. 226, p. 287-306.

Laiena, F., Gasparrini, M., Hamon, Y., IAnnace, A. And NADER, F.H., 2011, Diagenesis of Microbial Carbonates: A Case History from the Norian of the Italian Peninsula: American Association of Petroleum Geologists International Conference and Exhibition, Search and Discovery Article \#50553.

LAND, L.S., 1980, The isotopic and trace element geochemistry of dolomite: The state of the art: SEPM Special Publication, v. 28, p. 87-110.

LAND, L.S., 1985, The origin of massive dolomite: Journal of Geological Education, v. 33, p. 112125.

LONNEE, J., AND MACHEL, H.G., 2006, Pervasive dolomitization with subsequent hydrothermal alteration in the Clarke Lake gas field, Middle Devonian Slave Point Formation, British Columbia, Canada: American Association of Petroleum Geologists Bulletin, v. 90, p. 17391761.

LUCIA, F.J., 1995, Rock-fabric/petrophysical classification of carbonate pore space for reservoir characterization: American Association of Petroleum Geologists Bulletin, v. 79( 9), p. 12751300.

LUCIA, F.J. AND MAJOR, R.P., 1994, Porosity evolution through hypersaline reflux dolomitization in Purser, B., Tucker, M., Zenger, D., eds., Dolomites, IAS Special Publication, v. 21, p. 325341. 
MACHEL, H.G., 2004, Concepts and models of dolomitization: a critical reappraisal in Braithwaite, C.J.R., Rizzi, G. and Darke, G., eds., The Geometry and Petrogenesis of Dolomite Hydrocarbon Reservoirs, Geological Society, London, Special Publications, v. 235, p. 7-63.

Machel, H.G., MAson, R.A., MARIANO, A.N. AND MuCCI, A., 1991, Causes and emission of luminescence in calcite and dolomite in Barker, C.E. and Kopp, O.C., eds., Luminescence microscopy and spectroscopy: qualitative and quantitative applications, SEPM Short Course, v. 25 , p. $9-25$.

Mattes, B.W. And MounTJoy, E.W., 1980, Burial dolomitization of the Upper Devonian Miette buildup, Jasper National Park, Alberta in Zenger, D.H., Dunham, J.B. and Ethington, R.L., eds., Concepts and models of dolomitization, SEPM Special Publication, v. 28, p. 259-297.

MAZzoLI, S., 1992, Structural analysis of the Mesozoic Lagonegro Units in SW Lucania (Southern Italian Apennines): Studi Geologici Camerti, v. 12, p. 117-146.

MAzzoli, S. AND Helman, M., 1994, Neogene patterns of relative plate motion for Africa-Europe: some implications for recent central Mediterranean tectonics: Geologische Rundschau, v. 83, p. $464-468$.

Mazzoli, S., Corrado, S., De Donatis, M., Scrocca, D., Butler, R.W.H., Di Bucci, D., Naso, G., NiCOLAI, C. AND ZuCCONI, V., 2000, Time and space variability of "thin-skinned" and "thickskinned" thrust tectonics in the Apennines (Italy): Rendiconti Lincei Scienze Fisiche e Naturali, v. 11, p. 5-39.

Mazzoli, S., Barkham, S., Cello, G., Gambini, R., Mattioni, L., Shiner, P. And Tondi, E., 2001, Reconstruction of continental margin architecture deformed by the contraction of the Lagonegro basin, Southern Apennines, Italy: Journal of the Geological Society, London, v. 158(2), p. 309-320. 
Mazzoli, S., D’Errico, M., Adelga, L., Corrado, S., Invernizzi, C., Shiner, P. And Zattin, M., 2008, Tectonic burial and "young" $(<10 \mathrm{Ma})$ exhumation in the southern Apennines fold-andthrust belt (Italy): Geology, v. 36(3), p. 243-246.

MCARThur, J.M. AND HowARTh, R.J., 2004, Strontium isotope Stratigraphy in Gradstein, F.M., Ogg, J.G., Smith, A.G., eds., A Geological Time Scale 2004, Cambridge University Press.

Meister, P., McKenzie, J.A., Bernasconi, S.M. And Brack, P., 2013, Dolomite formation in the shallow seas of the Alpine Triassic: Sedimentology, v. 60, p. 270-291.

Melim, L.A., AND Scholle, P.A., 2002, Dolomitization of the Capitan Formation forereef facies (Permian, west Texas and New Mexico): seepage reflux revisited: Sedimentology, v. 49, p. $1207-1227$.

MERINO, E., CANALS, A. AND FlETCHER, R.C., 2006, Genesis of self-organized zebra textures in burial dolomites: Displacive veins, induced stress, and dolomitization: Geologica Acta, v. 4(3), p. 383-393.

Miconnet, P., 1988, Evolution Mesozoique du secteur de Lagonegro: Memorie della Società Geologica Italiana, v. 41, p. 321-330.

MonTAÑEZ, I.P., 1994, Late diagenetic dolomitization of Lower Ordovician, Upper Knox Carbonates: a record of the hydrodynamic evolution of the southern Appalachian Basin. American Association of Petroleum Geologists Bulletin, v. 78(8), p. 1210-1239.

MontaÑEZ, I.P. AND READ, J.F., 1992, Eustatic Control on Early Dolotimization of Cyclic Peritidal Carbonates: Evidence from the Early Ordovician Upper Knox Group, Appalachians: Geological Society of America Bulletin, v. 104, p. 872-886.

MoOre, C.H., CHOWdHURY, A. AND CHAN, L., 1988, Upper Jurassic Smackover platform dolomitization, northwestern Gulf of Mexico: a tale of two waters in Shukla, V. and Baker P. 
A., eds., Sedimentology and Geochemistry of Dolostones, SEPM Special Publication, v. 43, p. $175-189$.

Morad, S., Al-Aasm, I.S., NAder, F.H., Ceriani, A. Gasparrini, M. And Mansurbeg, H., 2012, Impact of diagenesis on the spatial and temporal distribution of reservoir quality in the Jurassic Arab D and C members, offshore Abu Dhabi oilfield, United Arab Emirates: GeoArabia, v. 17(3), p. 17-56.

Morrow, D.W., 1982, Diagenesis 2. Dolomite - Part2: Dolomitization models and ancient dolostones: Geoscience Canada, v. 9, p. 95-107.

MorSE, J.M. AND MACKENZIE, F.T., 1990, Geochemistry of sedimentary carbonates, 707 p.

Mostardini, F. AND Merlini, S., 1986, Appennino centro-meridionale: sezioni geologiche e proposta di modello strutturale: Memorie della Società Geologica Italiana, v. 35, p. 177-202.

MRESAH, M.H., 1998, The massive dolomitization of platformal and basinal sequences: proposed models from the Paleocene, Northeast Sirte Basin, Libya: Sedimentary Geology, v. 116, p. $199-226$.

Murgia, M.V., Ronchi, P. AND CERIANI, A., 2004, Dolomitization processes and their relationships with the evolution of an orogenic belt (Central Apennines and peri-adriatic foreland, Italy) in Swennen, R., Roure, F. and Granath, J.W., eds., Deformation, Fluid Flow, and Reservoir Appraisal in Foreland Fold and Thrust Belts, American Association of Petroleum Geologists Hedberg Series, p. 277-294.

Nielsen, P., Swennen, R., MucheZ, P. And KePpens, E., 1998, Origin of Dinantian zebra-dolomites south of the Brabant-Wales Massif, Belgium: Sedimentology, v. 45, p. 727-743.

Ogorelec, B., Dolenec, T., Pezdic, J., 1999, Isotope composition of O and C in Mesozoic carbonate rocks of Slovenia - effect of facies and diagenesis: Geologija, v. 42, p. 171-205. 
OLIVER, J., 1986, Fluids expelled tectonically from orogenic belts: their role in hydrocarbon migration and other geologic phenomena: Geology, v. 14, p. 99-102.

Passeri, L., Bertinelli, A. AND CiarapiCA, G., 2005, Paleogeographic meaning of the Late Triassic - Early Jurassic Lagonegro units: Bollettino della Società Geologica Italiana, v. 124, p. 231 245.

PataccA, E. AND SCANDOnE, P., 2003, Paleogeographic restoration of the Lagonegro basin. New constraints from subsurface data: Workshop on "Late Triassic-early Jurassic events in the framework of the Pangea break-up", Capri, abstract, p. 54-56.

PataccA, E. AND SCANDOnE, P., 2007, Geology of the Southern Apennines, in Mazzotti A., Patacca E., Scandone P., eds., Results of the CROP Project, Sub-project CROP-04 So, Special Issue, v. 7, p. 75-119.

PHILLIPS, W.J., 1972, Hydraulic fracturing and mineralization: Journal of the Geological Society (London), v. 128, p. 337-359.

PIERI, M., 1966, Tentativo di ricostruzione paleogeografico-strutturale dell'Italia centro-meridionale: Geologia Romana, v. 5, p. 407-424.

QING, H., Bosence, D.W.J. AND Rose, E.P.F., 2001, Dolomitization by penesaline seawater in Early Jurassic pertidal platform carbonates, Gibraltar, western Mediterranean: Sedimentology, v. 48, p. $153-163$.

RADKE, B.M. AND MATHIS, R.L., 1980, On the formation and occurrence of saddle dolomite: Journal of Sedimentary Petrology, v. 50, p. 1149-1168.

RIVERS, J.M., KYSER, T.K. AND JAMES, N.P., 2012, Salinity reflux and dolomitization of southern Australian slope sediments: the importance of low carbonate saturation levels: Sedimentology, v. 59, p. 445-465. 
RosenBAuM, J. AND SHEPPARD, S.M., 1986, An isotopic study of siderites, dolomites and ankerites at high temperatures: Geochimica et Cosmochimica Acta, v. 50, p. 1147-1150.

Roure, F., Swennen, R. Schneider, F., FAure, J.L., Ferket, H., Guilhaumou, N., Osadetz, K., Robion, PH. AND VANDEGINSTE V., 2005, Incidence of tectonics and natural fluid migration on reservoir evolution in foreland fold and thrust belts: Oil \& Gas Science and TechnologyRevue d'IFP, v. 60, p. 67-106.

SAller, A.H. AND Henderson, N., 1998, Distribution of porosity and permeability in platform dolomites: Insight from the Permian of west Texas: American Association of Petroleum Geologists Bulletin, v. 82, p. 1528-1550.

SCANDONE, P., 1967, Studi di geologia lucana: la serie calcareo-silico-marnosa e i suoi rapporti con l'Appennino calcareo: Bollettino Società dei Naturalisti in Napoli, v. 76, p. 1-175.

SCANDONE, P., 1972, Studi di geologia lucana: carta dei terreni della serie calcareo-silico-marnosa e note illustrative: Bollettino Società dei Naturalisti in Napoli, v. 81, p. 225-300.

SchettinO, A. AND TurCO, E., 2011. Tectonic history of the western Tethys since the Late Triassic: Geological Society of America Bulletin, v. 123, p. 89-105.

SHINER, P., BECCACINI, A. AND MAZZOLI, S., 2004, Thin-skinned versus thick-skinned structural models for Apulian carbonate reservoirs: Constraints from the Val D’Agri Fields: Marine and Petroleum Geology, v. 21, p. 805-827.

SiBLEY, D.F. AND GREGG, J.M., 1987, Classification of dolomite rock textures: Journal of Sedimentary Petrology, v. 54(3), p. 908-931.

SIBSON, R.H., 1990, Faulting and fluid flow, in Nesbitt B.E., ed., Fluids in tectonically active regimes of the continental crust, Mineralogical Association of Canada Short Course Handbook, v. 18, p. 93-132. 
SIMMS, M., 1984, Dolomitization by ground water-flow systems in carbonate platforms: Association of Geological Societies Transactions, v. 34, p. 411-420.

Stampfli, G.M. AND Borel, G.D., 2002, A plate tectonic model for the Paleozoic and Mesozoic constrained by dynamic plate boundaries and restored synthetic oceanic isochrones: Earth and Planetary Science Letters, v. 196(1-2), p. 17-33.

Sun, S.Q., 1995, Dolomite reservoirs: porosity evolution and reservoir characteristics: American Association of Petroleum Geologists Bulletin, v. 79, p. 186-204.

TAYLOR, T.R. AND SiBLEY, D.F., 1986, Petrographic and geochemical characteristics of dolomite in the Trenton Formation, Ordovician, Michigan Basin: Sedimentology, v. 33, p. 61-86.

TuCKER, M.E. AND Wright, V.P., 1990, Carbonate sedimentology. Blackwell Scientific, Oxford, $482 \mathrm{p}$.

Vasconcelos, C., McKenzie, J., Warthmann, R. And Bernasconi, S.M., 2005, Calibration of the $\delta^{18} \mathrm{O}$ paleothermometer for dolomite precipitated in microbial cultures and natural environments: Geology, v. 33(4), p. 317-320.

Veizer, J., Ala, D., Azmy, K., Bruckschen, P., Buhl, D., Bruhn, F., Carden, G.A.F., Diener, A., Ebneth, S., Godderis, Y., Jasper, T., Korte, C., Pawellek, F., Podlaha, O.G. And StRAUSS, H., $1999,{ }^{87} \mathrm{Sr} /{ }^{86} \mathrm{Sr}, \delta^{13} \mathrm{C}$ and $\delta^{18} \mathrm{O}$ evolution of Phanerozoic seawater: Chemical Geology, v. 161, p. 59-88.

Wahlman, G.P., 2010, Reflux Dolomite Crystal Size Variation in Cyclic Inner Ramp Reservoir Facies, Bromide Formation (Ordovician), Arkoma Basin, Southeastern Oklahoma: The Sedimentary Record, v. 8, p. 4-9. 
Wallace, M.W., Both, R.A., Ruano, S.M., Hach-Ali, P.F. And Lees, T., 1994, Zebra textures from carbonate-hosted sulfide deposits: Sheet cavity networks produced by fracture and solution enlargement: Economic Geology, v. 89, p. 1183-1191.

WARREN, J., 2000, Dolomite: occurrence, evolution and economically important association: Earth Science Reviews, v. 52, p. 1-81.

WhITAKER, F.F. AND SMART, P.L, 1990, Circulation of saline groundwaters through carbonate platforms: evidence from the Great Bahama Bank: Geology, v. 18, p. 200-204.

WooD, A.W., 1981, Extensional tectonics and birth of the Lagonegro Basin (Southern Italian Apennines): Neues Jahrbuch für Geologie und Paleontologie Abhandlungen, v. 161, p. 93131.

\section{FIGURE CAPTIONS}

Figure 1: Simplified geological map and cross-section A-A' of southern Apennines (modified after Mazzoli et al. 2000).

Figure 2: Paleogeographic reconstruction of the Lagonegro basin during the Upper Triassic (modified after Ciarapica 2007; Patacca and Scandone 2007). Intraplatform basins: Filettino (Fil), Monti Lattari and Picentini (LaP), Calabria (Cal). Bioconstructed marginal facies: Maddalena Mountains (Mad). The location of the studied outcrops has been inferred, based on the regional facies distribution of the Lagonegro succession (Scandone 1967; Miconnet 1988): Mount Marrone (M), San Fele (SF), Campagna (C), Pignola (P) and Lagonegro (L). The paleolatitude is based on Schettino and Turco (2011). 
Figure 3: Stratigraphic schemes of the Apenninic platform and Lagonegro basin successions. DBM dolomia massiva di base; MAA calcari e marne ad Avicula e Miophoria; DBS dolomia superiore; CPL calcari a Palaeodasycladus; CDO calcari oolitici ed oncolitici; CCM calcari con Cladocoropsis e Clypeina; CRQ calcari con requienie e gasteropodi; RDT calcari a radiolitidi; TRN Trentinara; FCE Cerchiara; BIF Bifurto; CUS Cusano; LNG Longano; FPJ Pietraroja; FAC Monte Facito; SLC calcari con selce; STS scisti silicei; FYG flysch galestrino; FYR flysch rosso.

Figure 4: Geologic map of southern Apennines (modified after Butler et al. 2004). The dashed red line represents the boundary between the northern and the southern areas. Magenta and green polygons indicate respectively the outcrop distribution of dolomitized and undolomitized limestones of the Calcari con selce Formation. Magenta dots represent the location of the wells in which the cherty carbonates are almost completely dolomitized (1-Acerno 1; 2-San Fele 1; 3-Monte Foi 1; 4-Monte Gargaruso 1; 5-Frosolone 2). Pink and green dots represent the location of the wells in which the cherty limestones are only partially dolomitized or not dolomitized, respectively. The area enclosed in the dashed frame is showed in Fig. 5.

Figure 5: Simplified geological map of the southern area displaying the location of outcrops and wells. This area is enclosed in the dashed frame of Fig. 4. 1) Vietri di Potenza; 2) Tito-Satriano; 3) Pignola quarry; 4) La Sellata-Rifreddo; 5) Fiumarella d'Anzi; 6) Monteforte; 7) Abriola; 8) Fosso di Fossacupa; 9) Madonna del Sasso; 10) Mount Arioso; 11) Mount Tigliano; 12) Manca di Vespe; 13) Pergola-Marsico Nuovo.

Figure 6: Precursor limestones and dolomites of the Calcari con selce Formation. A) Limestones at Manca di Vespe containing chert nodules (white arrows). Bedding parallel stylolites are well developed. Scale bar is $10 \mathrm{~cm}$. B) Thinly bedded dolomites at Campagna. C) Dolomite with laminations crosscut by veinlets of saddle dolomite (Campagna). Finger for scale. D) Alternation of 
dolomite beds and siliciclastic beds (Campagna). Hammer for scale is $30 \mathrm{~cm}$ long. E) Bedded dolomite at Mount Pierno. Hammer for scale. F) Massive block of dolomite containing chert nodules (black arrows) at Mount Pierno; scale bar is $15 \mathrm{~cm}$.

Figure 7: Dolomites outcropping in the southern area (Pignola - high Val d'Agri). A)

Dolomitization front (red line) crosscutting the stratification (Pignola quarry). A pressure solution cleavage (dashed lines) is well developed both in host limestones (L) and dolomites (D) and displays the same spacing in both lithologies. B) Zebra structures with hydrofractured breccia features which are confined by an overlying chert layer (red arrow; Madonna del Sasso). Scale bar is $15 \mathrm{~cm}$. C) Zebra structures obliquely oriented (black arrow) with respect to the bedding (La Sellata-Rifreddo). Cleavage planes are sub-vertical. D) Zebra structures crosscut by subvertical white sparry dolomite veins (Madonna del Sasso). Scale bar is $10 \mathrm{~cm}$. E) Dolomitic breccia consisting of clasts of gray replacive dolomite engulfed by white dolomite cements (Madonna del Sasso). F) Brecciated fabric (Madonna del Sasso). Scale bar is $20 \mathrm{~cm}$.

Figure 8: Stratigraphic logs of the studied wells. The Calcari con selce Formation occurs in the three wells and is commonly dolomitized or partially dolomitized.

Figure 9: Photomicrographs of the precursor limestone. A) Wackestone with thin-shelled bivalves and calcified radiolarians, crosscut by a calcite vein. Plane-polarized light (Madonna del Sasso). B) CL image of $\mathrm{A}$. The wackestone shows a dull orange CL, whereas the calcite vein is nonluminescent. C) Partially dolomitized mudstone crosscut by a calcite vein (Pignola quarry). Dolomite crystals present a planar-e texture. D) CL image of C. The limestone has a dull orange CL, whereas dolomite rhombs have a bright red CL. The calcite vein is non-luminescent.

Figure 10: Photomicrographs of dolomites from northern area. A) Planar-s mosaic of dolomite crystals of 40-80 $\mu \mathrm{m}$ (Mt. Marrone, Molise). Plane-polarized light. B) CL image of a planar-s 
dolomite from Campagna displaying dull red luminescence. C) Ghost of a bioclast (red arrow; Mt. Pierno). Plane-polarized light. D) Sedimentary breccia (Mt. Pierno). The matrix is calcareous, whereas the clasts are dolomitized. Plane-polarized light. E) Vug partially cemented by saddle dolomite crystals (Mt. Pierno). Plane-polarized light. F) CL image of E. The crystals present growth zones showing different CL colors (from dull red to non-luminescent). G) Chert (Ch) nodule almost completely replaced by planar-e dolomite crystals (Mt. Pierno). Plane-polarized light. H) CL image of C. The dolomite crystals display a dull red CL.

Figure 11: Photomicrographs of dolomites from southern area. A) Doll showing two main size populations: medium $(40-80 \mu \mathrm{m})$ crystals are on the left of the picture, whereas coarser crystals $(150-200 \mu \mathrm{m})$ are on the right. Plane-polarized light. (Mt. Tigliano) B) CL image of A. The crystals display a dull red and unzoned CL. C) Dol2 crystals that point to a cavity and exhibit a zoning due to alternation of zones with different fluid inclusions content. Plane-polarized light. (Mt. Tigliano) D) CL image of C. The crystals display growth bands having different CL. E) Dol2 given by curved crystals, uniformly cloudy (Pignola quarry). Dol3 is the last cement phase and it is also present in the vein that crosscut Dol2 crystals. Plane-polarized light. F) CL image of E. The last growth zone of the Dol2 shows a dull orange CL, whereas Dol3 is non-luminescent. G) Dol2 crystals and a quartz-filled cavity (Vietri di Potenza). Plane-polarized light. H) CL image of G in which Dol2 displays a dull red color.

Figure 12: Photomicrographs of dolomites from the studied wells. A) Mosaic of fine dolomite crystals (20-30 $\mu \mathrm{m})$ from the Acerno 1 well. Plane-polarized light. B) Planar-s mosaic with crystals of mostly 100-200 $\mu \mathrm{m}$ (Acerno 1 well). Plane-polarized light. C) Planar-s mosaic having crystals of 100-200 $\mu \mathrm{m}$ (Mt. Gargaruso 1 well). Plane-polarized light. D) CL image of C. The mosaic presents a uniform red CL. E) Fragment of saddle dolomite cement from the Mt. Gargaruso 1 cuttings. 
Plane-polarized light. F) CL image of E displaying a red luminescence. The edges of the crystals show alternating bands with different CL color (white arrow).

Figure 13: Covariation plot between $\delta^{18} \mathrm{O}$ and $\delta^{13} \mathrm{C}$ of the studied dolomites. The black ellipse represents the isotopic composition of the undolomitized limestones (data from Iannace et al. 2012). The isotope composition of Upper Triassic seawater (Veizer et al. 1999; Korte et al. 2005) is reported in the dashed frame. The black frame represents the isotopic signature of dolomites from the Norian Apenninic platform (Iannace 1991), whereas the blue frame shows the isotope compositions of dolomites from the Norian build-ups and slope facies of the same platform (Laiena et al. 2011).

Figure 14: Covariation plot between the minor elements concentrations in the studied dolomites. A) Mn vs. Sr. B) Fe vs. Sr. C) Mn vs. Fe.

Figure 15: Covariation plot between $\delta^{18} \mathrm{O}$ and ${ }^{87} \mathrm{Sr} /{ }^{86} \mathrm{Sr}$ ratios for the studied dolomites. Values for the undolomitized limestone (from Iannace et al. 2012) are represented by the black ellipse. The isotope composition of Upper Triassic seawater (Veizer et al. 1999; McArthur and Howarth 2004) is reported in the dashed frame.

Figure 16: Photomicrographs of the studied fluid inclusions. A) Dol2 crystal showing fluid inclusions in the core (C), along growth zones (GZ), and along the crystal edge (CE). B) Crystallographically controlled fluid inclusions at room temperature, occurring in an inclusion poor crystal edge.

TABLE CAPTIONS 
Table 1: Microthermometry and petrography results of two-phase (liquid + vapor) fluid inclusions for nine dolomite samples from different localities. The inclusion size at room temperature is given as length in $\mu \mathrm{m}$. The most common inclusions shapes for each sample are indicated:

crystallographically controlled (CC); rectangular (R); elongated (E); irregular (I); triangular (T). The mode and range values of homogenization temperatures (Th) and ice melting temperatures (Tm) are reported. In parenthesis, the number of Th and Tm measurements, accomplished for each sample, is reported. 


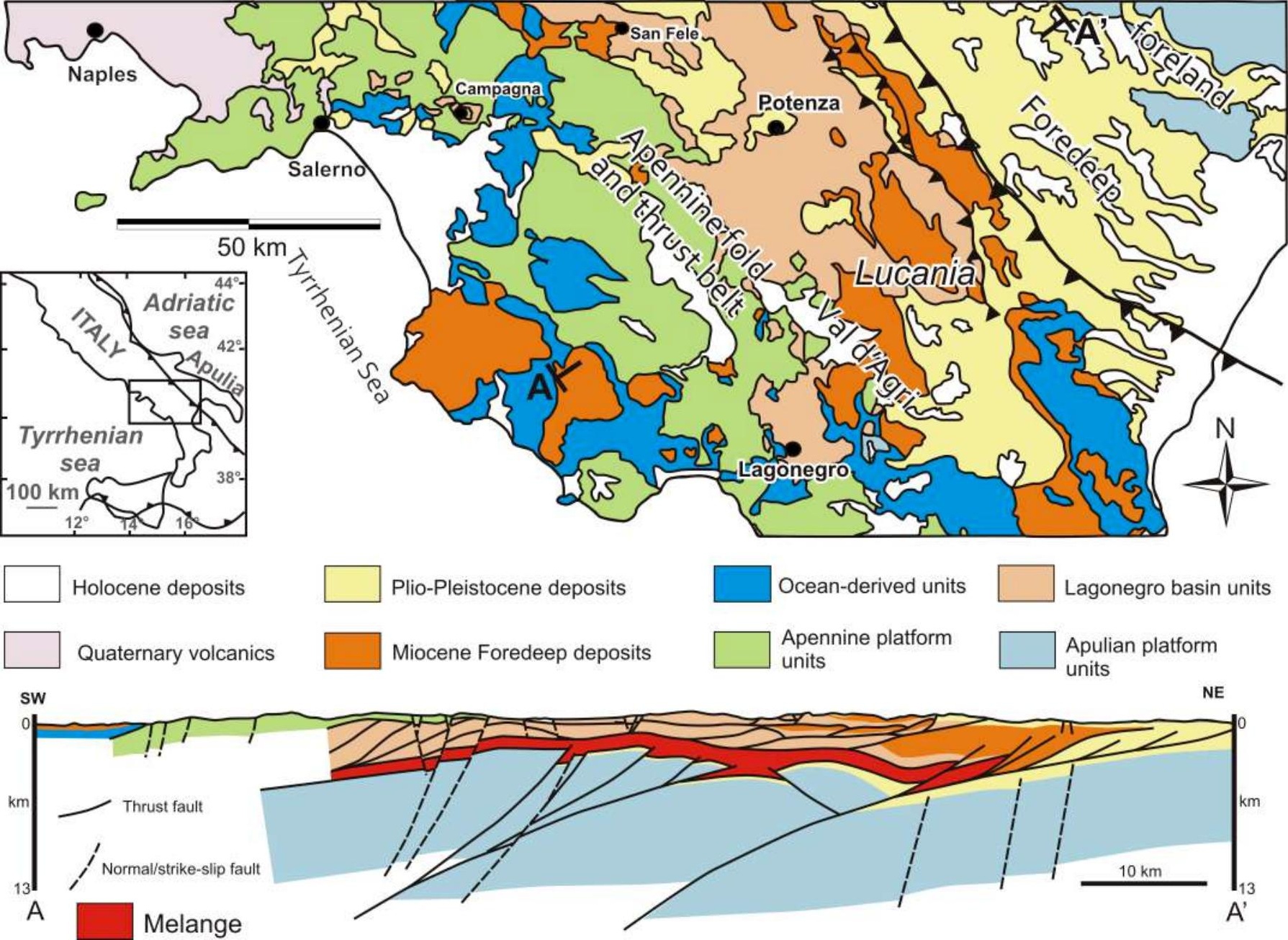



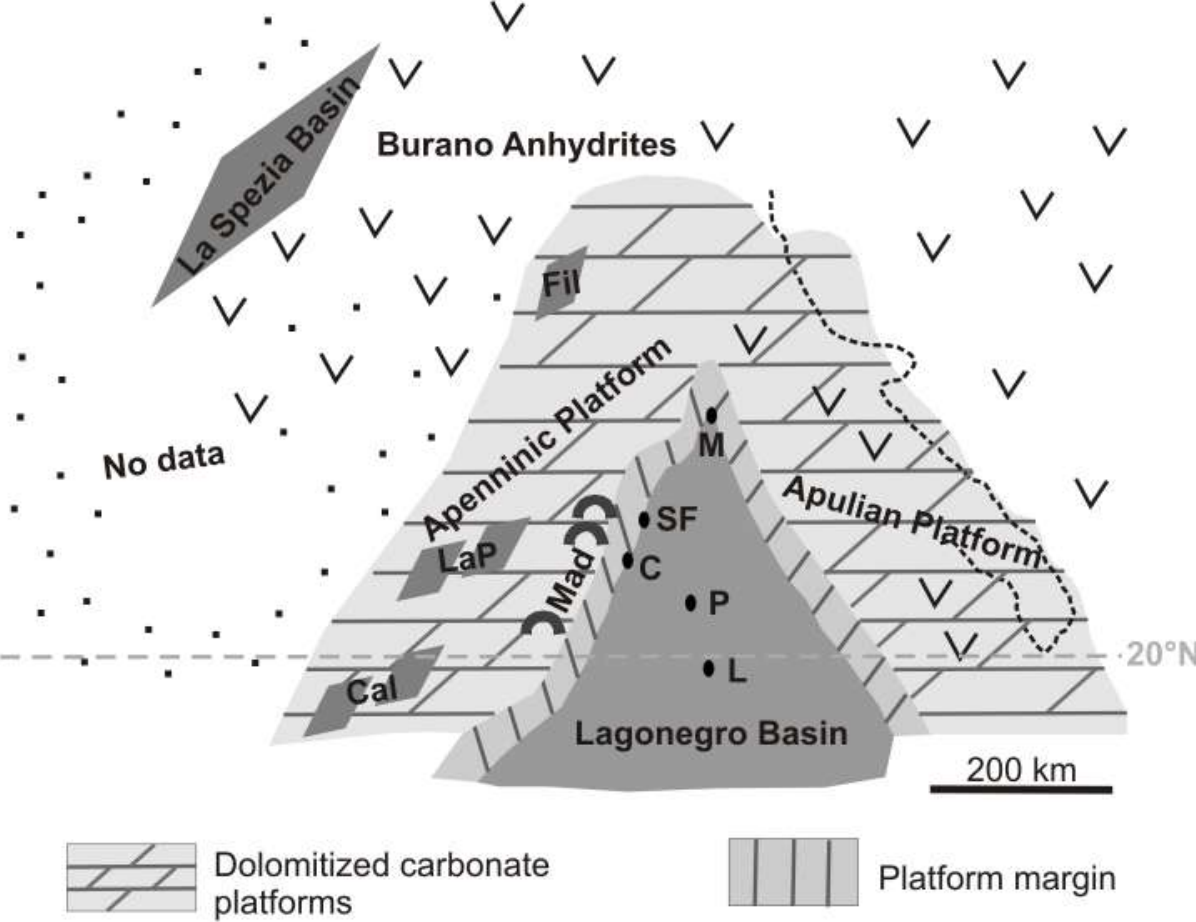

Dolomitized carbonate platforms

Pelagic deposits

- Siliciclastic deposits

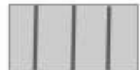

Platform margin
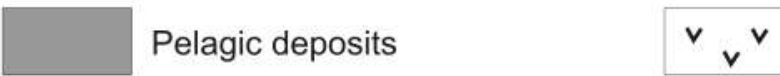

Evaporites

ค B Bioconstructions

Strike-slip basins 


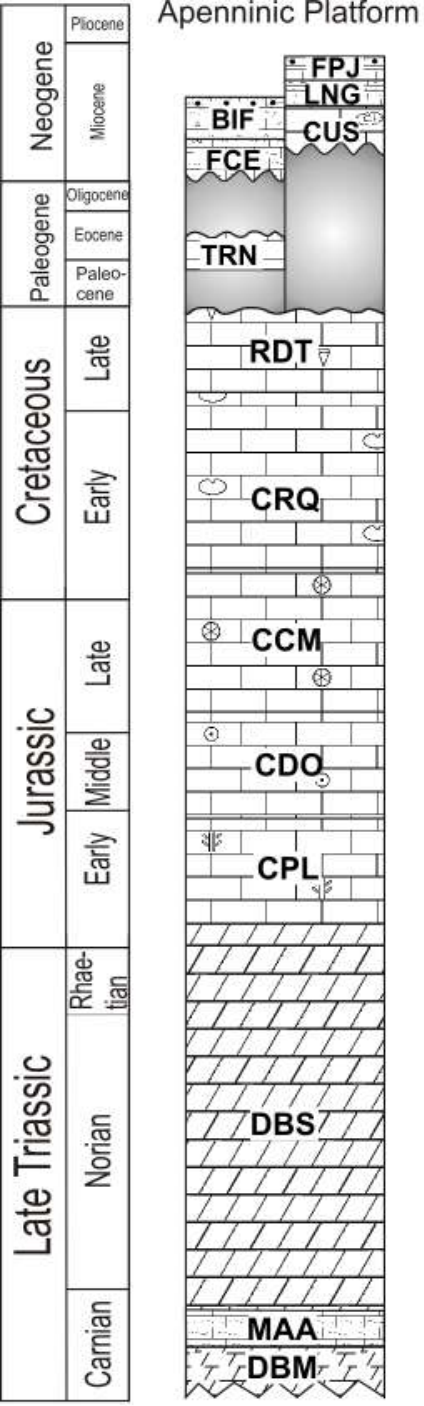

Lagonegro Basin
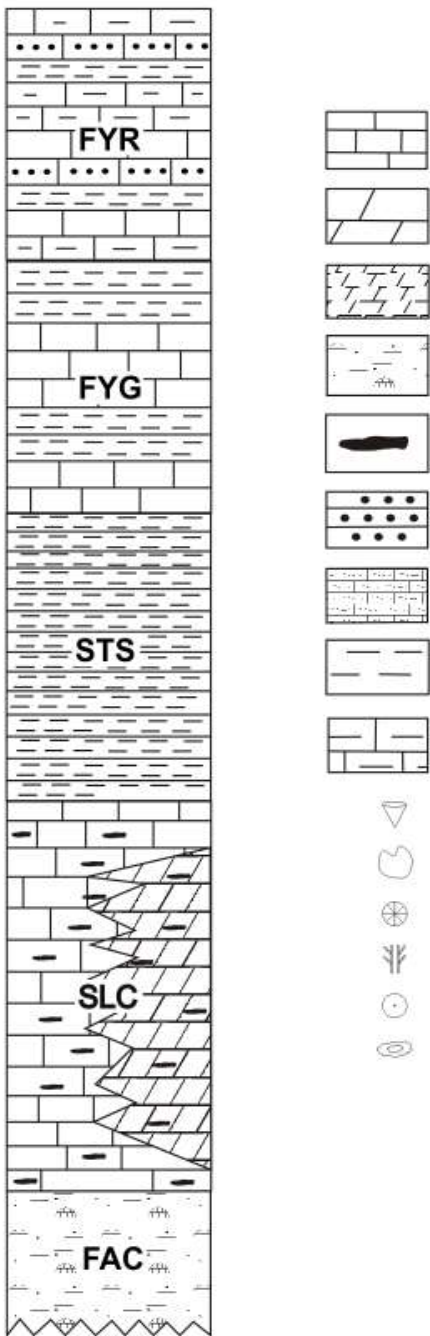

Limestones
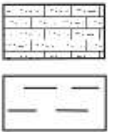

Radiolarites and shales

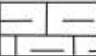

$\otimes \quad$ Rudist

Requienid

Cladocoropsis

Palaeodasycladus

Ooid

Rhodolith 


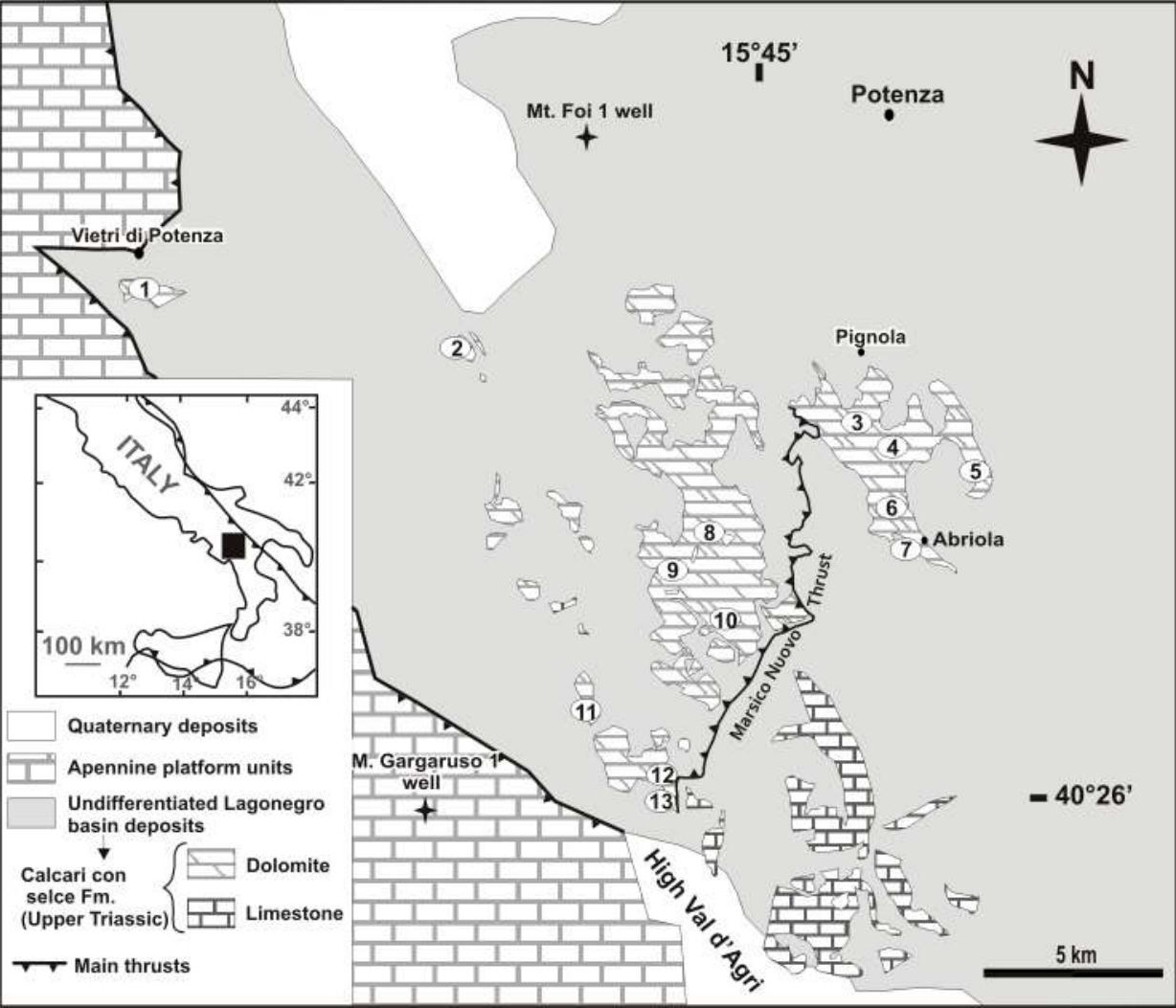




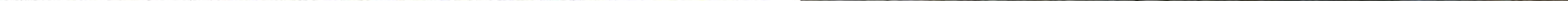


Monte Gargaruso 1

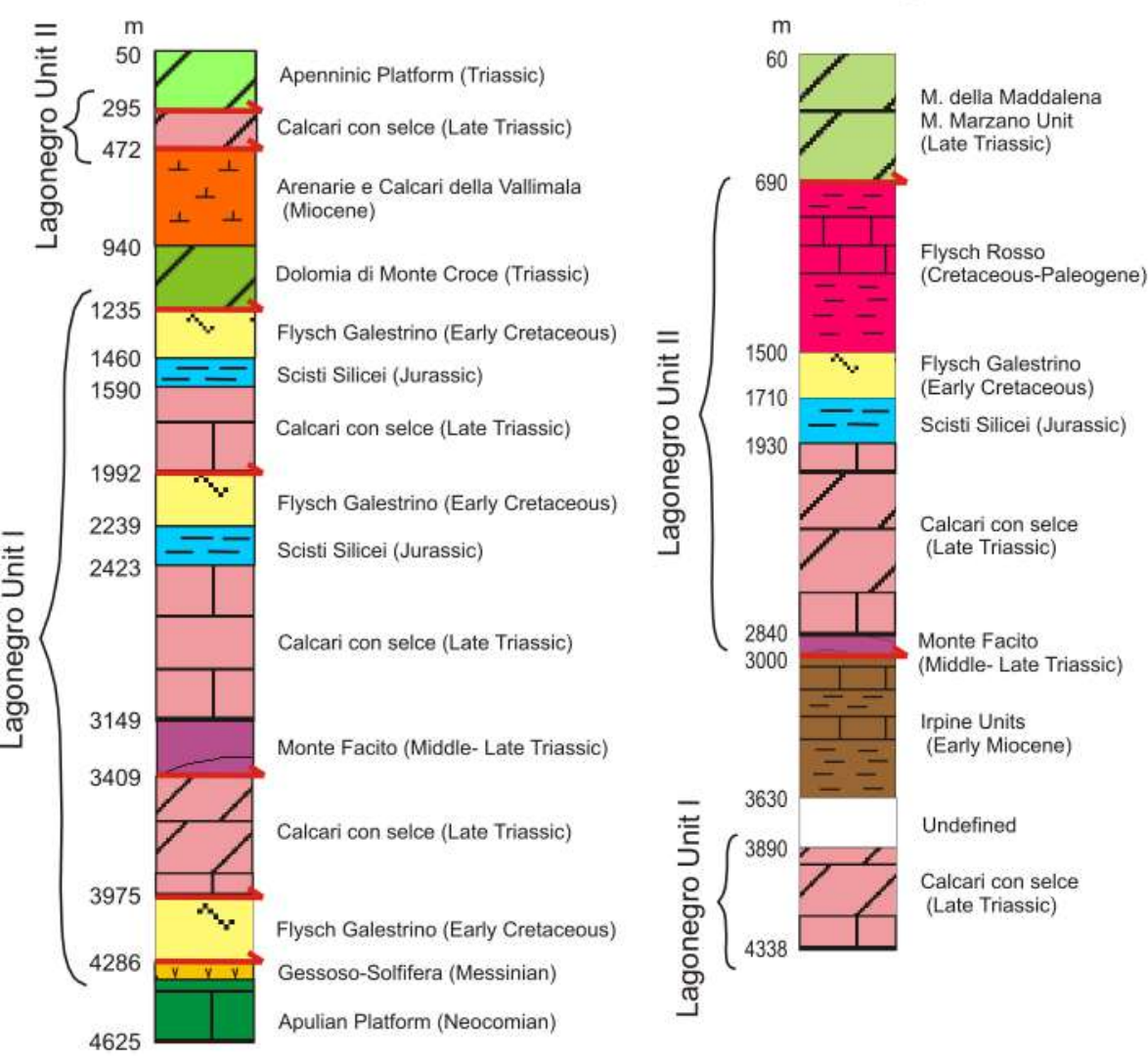

Monte Foi 1

m

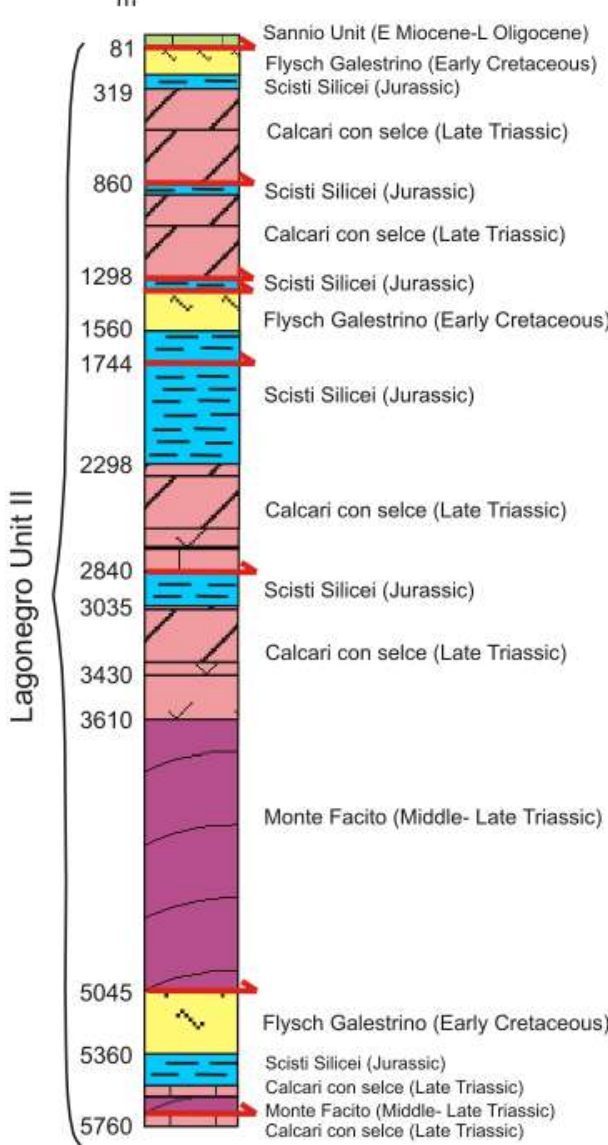

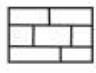
Limestones

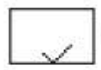
Calcareous dolomites

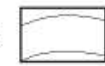
Siliceous marls and shales

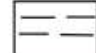

Carbonate buildups, radiolarites, shales, arenites

Radiolarites and shales $\vee \vee v$ Evaporites

$\perp \perp$ Argillaceous limestones 


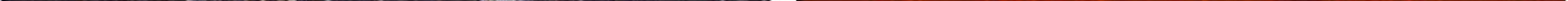


- Northern area

O Northern area cement

O Southern area Dol1

O Southern area Dol2+Dol3

$\Delta$ Acerno 1 well

$\triangle \mathrm{Mt}$. Gargaruso 1 and Mt. Foi 1 wells

O

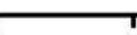

0 ○

。
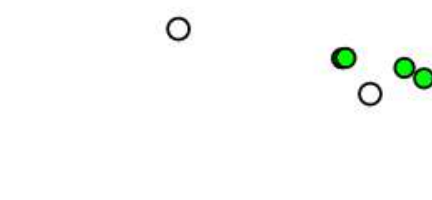

$-12 \quad-10$

10

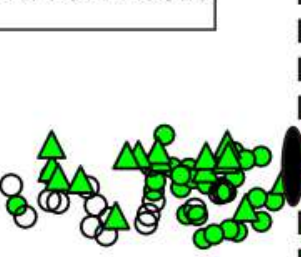

$\triangle$

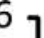


- Northern area

o Southern area Dol1

O Southern area Dol2+Dol3

$\triangle$ Mt. Gargaruso 1 well
0.7097

0.7093

0.7089

O

0

o

O

$\Delta$

$-14 \quad-12 \quad-10$

$-8$

$-6$

$-2$

$-4$

0.7073

$\delta^{18} \mathbf{O}$ (\% PDB) 


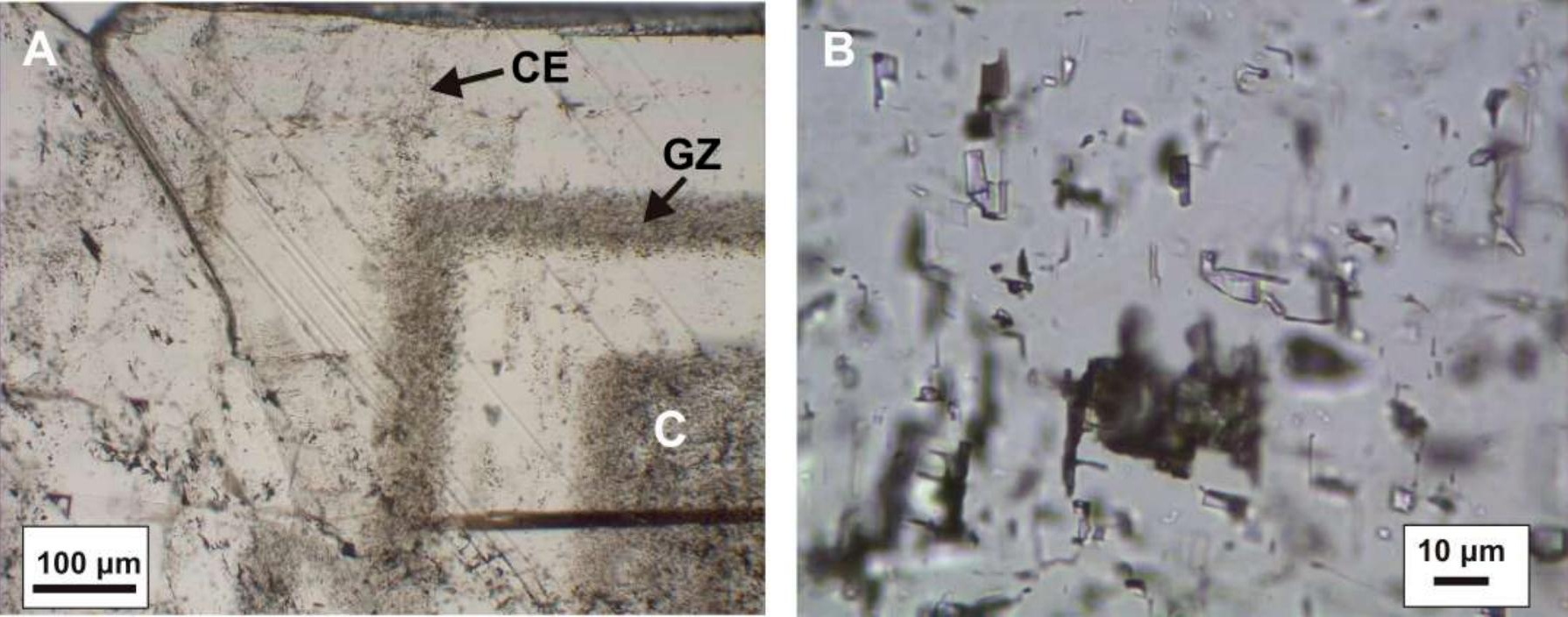


Table 1: Microthermometry and petrography results of two-phase (liquid + vapor) fluid inclusions for nine dolomite samples from different localities.

\begin{tabular}{|c|c|c|c|c|c|c|c|}
\hline \multirow[b]{2}{*}{ Sample } & \multirow[b]{2}{*}{ Locality } & \multirow[b]{2}{*}{ Shape } & \multirow[b]{2}{*}{ Size $(\mu \mathrm{m})$} & \multicolumn{2}{|c|}{$\operatorname{Th}\left({ }^{\circ} \mathrm{C}\right)$} & \multicolumn{2}{|c|}{$\operatorname{Tm}\left({ }^{\circ} \mathrm{C}\right)$} \\
\hline & & & & mode & range & mode & range \\
\hline TG40B & Fiumarella d'Anzi & $\mathrm{CC}-\mathrm{R}$ & $<10$ & $95(47)$ & $75 / 117$ & - & $-1.8 /-2.6$ \\
\hline TG61B & $\begin{array}{l}\text { Madonna del } \\
\text { Sasso }\end{array}$ & $R-E$ & $<10$ & $85(45)$ & $67 / 104.5$ & - & $-1.1 /-1.3$ \\
\hline TG81B & Vietri di Potenza & $\mathrm{CC}-\mathrm{R}$ & $<5$ & $115(31)$ & $87 / 121$ & - & $-1.9 /-2.7$ \\
\hline TG84B & Tito - Satriano & CC-E & $<10$ & $115(32)$ & $87 / 129$ & $-2.9(6)$ & $-1.2 /-2.9$ \\
\hline TG89B & Mount Arioso & CC-E & up to 15 & $95(32)$ & $86 / 115$ & - & $-1.5 /-3.2$ \\
\hline TG104B & Mount Tigliano & CC-I & up to 15 & $105(47)$ & $71 / 118$ & $-1.1(6)$ & $-1.1 /-3.2$ \\
\hline GA2490 & $\begin{array}{c}\text { Mt. Gargaruso } 1 \\
\text { well }\end{array}$ & CC-R & $<5$ & - & - & - & $-2.2 /-4.0$ \\
\hline GA4105 & $\begin{array}{c}\text { Mt. Gargaruso } 1 \\
\text { well }\end{array}$ & E-T & $<10$ & - & - & - & - \\
\hline GA4145 & $\begin{array}{c}\text { Mt. Gargaruso } 1 \\
\text { well }\end{array}$ & CC-R & $5-10$ & - & - & - & $-1.7 /-3.7$ \\
\hline
\end{tabular}

The inclusion size at room temperature is given as length in $\mu \mathrm{m}$. The most common inclusions shapes for each sample are indicated: crystallographically controlled (CC); rectangular (R); elongated $(\mathrm{E})$; irregular (I); triangular (T). The mode and range values of homogenization temperatures (Th) and ice melting temperatures $(\mathrm{Tm})$ are reported. In parenthesis, the number of Th and Tm measurements, for each sample, is reported. 